\title{
Cross-reactivity of neutralizing antibody and its correlation with circulating $T$ follicular cells in recovered COVID-19 individuals
}

Jian Zhang ${ }^{1,15}$, Qian Wu ${ }^{1,15}$, Ziyan Liu ${ }^{1,15}$, Qijie Wang ${ }^{2,15}$, Jiajing Wu ${ }^{3,12,15}$, Yabin $\mathrm{Hu}^{1,15}$, Tingting Bai ${ }^{4}$, Ting $\mathrm{Xie}^{2}$, Mincheng Huang ${ }^{2}$, Tiantian $\mathrm{Wu}^{5}$, Danhong Peng ${ }^{2}$, Weijin Huang ${ }^{3}$, Kun Jin ${ }^{1}$, Ling Niu ${ }^{1}$, Wangyuan Guo ${ }^{1}$, Dixian Luo ${ }^{1}$, Dongzhu Lei ${ }^{1}$, Zhijian Wu ${ }^{1}$, Guicheng $\mathrm{Li}^{1}$, Renbin Huang ${ }^{1}$, Yingbiao Lin ${ }^{1}$, Xiangping Xie ${ }^{2}$, Shuangyan $\mathrm{He}^{2}$, Yunfan Deng ${ }^{6}$, Jianghua Liu ${ }^{7}$, Weilang $\mathrm{Li}^{8}$, Zhongyi Lu', Haifu Chen $^{10}$, Ting Zeng ${ }^{2}$, Qingting Luo ${ }^{11}$, Yi-Ping Li ${ }^{5,16}$, Youchun Wang ${ }^{3,16}$, Wenpei Liu ${ }^{1}$, 4, 13,16, Xiaowang $Q u^{1,14,16}$

${ }^{1}$ Translational Medicine Institute, The First People's Hospital of Chenzhou, University of South China, Chenzhou, 423000, China

2 The Central Hosptial of Shaoyang, Shaoyang, 422000, China

${ }^{3}$ National Institutes for Food and Drug Control, Key Laboratory of the Ministry of Health for Research on Quality and Standardization of Biotech Products, Key Laboratory of Biological Product Quality Research and Evaluation of National Medical Products Administration, Beijing 102629, China

${ }^{4}$ The First School of Clinical Medicine, Southern Medical University, Guangzhou, 510515, China

${ }^{5}$ Institute of Human Virology, Zhongshan School of Medicine, and Key Laboratory of Tropical Disease Control of Ministry of Education, Sun Yat-sen University, Guangzhou 501180, China

${ }^{6}$ The Longhui People's Hospital, Longhui, 422200, China

${ }^{7}$ The Xinshao People's Hospital, Xinshao, 422900, China

${ }^{8}$ The Dongkou People's Hospital, Dongkou, 422300, China

${ }^{9}$ The Shaoyang People's Hospital, Shaoyang, 422100, China

${ }^{10}$ The Suining People's Hospital, Suining, 422600, China 
11 The Baoqing Psychiatric Hospital, Shaoyang, 422000, China

${ }^{12}$ Wuhan institute of biological products CO., LTD, Wuhan, 430200, China

${ }^{13}$ School of Laboratory Medicine and Biotechnology, Southern Medical University, Guangzhou, 510515, China

${ }^{14}$ School of Public Health, Southern Medical University, Guangzhou, 510515, China

${ }^{15}$ These authors contributed equally to this study.

${ }^{16}$ Corresponding authors

\section{Correspondence should be addressed to}

Xiaowang Qu, Professor

Translational Medicine Institute, The First People's Hospital of Chenzhou, University of South China, Chenzhou, 423000, China

Email: quxiaowang@163.com

Wenpei Liu, Associate Professor

Translational Medicine Institute, The First People's Hospital of Chenzhou, University of South China, Chenzhou, 423000, China

Email: mailto: wenpeiliu_2008@foxmail.com

\section{Youchun Wang, Professor}

National Institutes for Food and Drug Control, Key Laboratory of the Ministry of Health for Research on Quality and Standardization of Biotech Products, Key Laboratory of Biological Product Quality Research and Evaluation of National Medical Products Administration, Beijing 102629, China

Email: wangyc@nifdc.org.cn 
medRxiv preprint doi: https://doi.org/10.1101/2020.06.12.20129460; this version posted June 14, 2020. The copyright holder for this preprint (which was not certified by peer review) is the author/funder, who has granted medRxiv a license to display the preprint in perpetuity.

All rights reserved. No reuse allowed without permission.

\section{Yi-Ping Li, Professor}

Institute of Human Virology, Zhongshan School of Medicine, and Key Laboratory of

Tropical Disease Control of Ministry of Education, Sun Yat-sen University, Guangzhou 501180, China

Email: lyiping@mail.sysu.edu.cn

Running title: $\mathrm{nAb}$ associated with Tfh cells in COVID-19 convalescents 


\section{Summary}

Seroconversion appeared early after COVID-19 onset, and convalescent sera therapy benefit some critical patients. However, neutralizing antibody (nAb) in convalescents is largely unknown. We found that $97.01 \%(65 / 67)$ of COVID-19 convalescents maintained IgG antibodies with high binding and avidity to SARSCoV-2 spike subunits S1 and S2, and 95.52\% (64/67) had neutralization activity against SARS-CoV-2 pesudovirus, one month after discharge (median ID $_{50}, 2.75$; IQR, 2.34-3.08). Some sera exhibited cross-neutralization against SARS-CoV (76.12\%), MERS-CoV (17.91\%), or both (10.45\%). Interestingly, individuals recovered from severe disease (severe group) had nAbs with binding and neutralization titers higher than non-severe group. Severe group appeared a rapid increase of lymphocytes and a high proportion of circulating $\mathrm{CXCR3}^{+} \mathrm{Tfh}$ cells. Interestingly, the later were spike-specific and positively correlated with SARSCoV-2 nAb titers. All subjects had no autoimmunity. Our findings provide novel insights into nAb responses in COVID-19 convalescents and facilitate treatment and vaccine development for SARS-CoV-2 infection. 


\section{Main Text}

Coronavirus Disease 2019 (COVID-19), an emerging disease caused by SARS-CoV-2 infection $^{1-3}$, has globally spread causing $>4.5$ million infections and 0.3 million deaths ${ }^{4}$. Symptoms of COVID-19 range from asymptomatic, mild, moderate to severe ${ }^{5,6}$. No specific drug and vaccine available for COVID-19, and treatments are primarily the supportive cares. Convalescent sera have proven to improve clinical presentation and reduce mortality of critical patients ${ }^{7,8}$. Serum SARS-CoV-2-specific $\operatorname{IgM}^{9-12}$ and in most of patients $\mathrm{IgG}^{13-15}$ were detectable during 4-to-14 days after symptom onset, though $\mathrm{T}$ and B cells decreased dramatically at early acute phase of infection. Few studies reported that neutralizing antibody $(\mathrm{nAb})$ responses to viral spike protein were variable in recovered COVID-19 individuals ${ }^{1,16,17}$. Monoclonal $\mathrm{nAbs}$ have been isolated from COVID-19 convalescents and are facilitating clinical trials of antibody therapy and vaccine development ${ }^{18,19}$. However, nAb responses in COVID-19 convalescents are largely unclear, in respect to neutralizing activity, avidity, and cross-neutralization with other coronaviruses. Although lymphocytes play essential role in antibody initiation and maturation, the association of $\mathrm{T}$ cell populations with SARS-CoV-2-specific $\mathrm{nAb}$ responses remains unknown.

In this study, we recruited 67 recovered COVID-19 individuals. Blood was drawn on day 28 after discharge. The baseline clinical characteristics and laboratory findings on admission was retrospectively analyzed (Extend Data Tables 1 and 2). The binding titer and avidity of serum IgG against S1 and S2 subunits of SARS-CoV-2 spike antigen were examined by ELISA assays (Methods, Online content). All recovered patients had robust anti-S1 (median, 4.61; IQR, 4.01-4.61) and anti-S2 (median, 4.91; IQR, 4.61-5.52) IgG 
medRxiv preprint doi: https://doi.org/10.1101/2020.06.12.20129460; this version posted June 14, 2020. The copyright holder for this preprint

antibodies, and anti-S2 titers were significantly higher than anti-S1 ( $<<0.001)$ (Fig. 1a and Extend Data Table 3). All 67 subjects showed avidity index to S1 (median, 44.5; IQR, 34.5-51.75) and S2 (median, 58; IQR, 49-67) antigens (3 samples with marginal binding), and avidity indices to S2 were higher ( $\mathrm{p}<0.001)$ (Fig.1b), in consistence with the endpoint titers (Fig. 1a). Next, we tested the antibody binding to spike proteins from both SARS-CoV and MERS-CoV. The results showed that 38.81\% (26/67) and 73.13\% (49/67) had cross-reactions with S1 of SARS-CoV and S2 of MERS-CoV, but not with S1 of MERS-CoV (Fig. 1c). No binding to SARS-CoV S1, and only 6.67\%, 1.67\% sera from 60 healthy controls showed binding to MERS-CoV S1 and S2, respectively (Extend Data Table 4). We did not test S2 of SARS-CoV due to no qualified antigen available.

To determine the neutralizing and cross-neutralizing activities, we developed SARSCoV-2 spike-based pesudovirus for neutralization experiments, in parallel with previously developed SARS-CoV and MERS-CoV pesudoviruses ${ }^{20}$. Of 67 individuals, $65(97.01 \%)$ elicited nAbs neutralizing SARS-CoV-2 pesudovirus (median $\mathrm{ID}_{50}, 2.75$; IQR 2.34-3.08) (Fig. 1d and e), and neutralization titers were positively correlated with the endpoint titers of SARS-CoV-2 S1- and S2-specific antibodies (Extend Data Fig. 1ac). Interestingly, $51(76.12 \%, 65.67 \%$ plus $10.45 \%)$ sera showed cross-neutralization with SARS-CoV, 12 (17.91\%, 7.46\% plus 10.45\%) with MERS-CoV, and 7 (10.45\%) with both (Fig. 1f). Sera with and without cross-neutralization activity had no differences in neutralization titers for SARS-CoV-S2 (Extend Data Fig. 2a and b), but crossneutralization activity for SARS-CoV and MERS-CoV were significantly weaker than for SARS-CoV-2 (Extend Data Fig. 2c-e). These findings demonstrate that majority of recovered COVID-19 individuals elicited and maintained robust nAb responses to SARS- 
CoV-2. Some antibodies had cross-binding and neutralizing activities against SARS-CoV and/or MERS-CoV. No autoimmune antibodies were detected in recovered COVID-19 individuals (Extend Data Table 5).

Patients with severe and mild COVID-19 symptoms were reported with distinct clinical and immunological presentations ${ }^{9-11}$. Here, we categorized all 67 recovered individuals into "severe" (17/67) and "non-severe" (50/67) groups, according to the severity of disease that patients had suffered (Extend Data Table 1). Compared to non-severe group, severe group exhibited higher titers of anti-S1 $(p=0.012)$ and anti-S2 antibodies $(p=0.011)$ (Fig. 2a) and higher neutralization titers (p=0.001) (Fig. 2b), but no difference for binding avidity (Fig. 2c). Next, we analyzed the factors that may associate with nAbs responses and found that $\mathrm{nAb}$ response was correlated with the severity of disease (Table 1), though older age $(p<0.001)$, longer course of disease $(p=0.007)$, more comorbidities $(p=0.044)$, and underlying diseases $(\mathrm{p}<0.001)$ were higher in severe group (Extend Data Table 1). Further analysis of lymphocyte counts at five time-points, including admission, midcourse, discharge, day 14 and 28 after discharge revealed that majority 16/17 (94.12\%) of severe group exhibited lower lymphocyte count on admission, in line with a recent report $^{5}$, while non-severe group that was at the bottom line of normal range (1.2$3.5 \times 10^{9} / \mathrm{L}$ ) (Fig. 2d). Unlike slow increase in non-severe group, lymphocyte counts of severe group increased gradually during hospitalization and restored to normal on discharge (median, from 0.65 to $2.28 \times 10^{9} / \mathrm{L}$ ), maintained at this level for two weeks, then unexpectedly rebound from day 14 to 28 after discharge, crossing and having mean value higher than that of non-severe group ( $\mathrm{p}=0.08$ ) (Fig. 2d). Severe group had higher fold 
change of lymphocytes, related to admission respectively, at all later time points $(\mathrm{p}<0.01)$ (Fig. 2e).

Next, we investigated whether the increased lymphocytes contributed to nAbs production. Circulating $\mathrm{T}$ follicular helper (Tfh) cells, counterparts of germinal center Tfh cells ${ }^{21}$, are important for maturation and antibody production of T-dependent $\mathrm{B}$ cells ${ }^{22,23}$. We found that severe and non-severe groups had no difference in circulating Tfh frequency (Fig. 3a), however, $\mathrm{CXCR}^{+}$Tfh cells $(\mathrm{p}=0.016)$ and $\mathrm{CXCR}^{+} / \mathrm{CXCR} 3^{-}$Tfh cells $(\mathrm{p}=0.014)$ were higher in severe group (Fig. 3b-d). Interestingly, nAb titers were positively correlated with $\mathrm{CXCR}^{+}$Tfh frequency $(\mathrm{r}=0.486, \mathrm{p}=0.012)$ and the ratio of $\mathrm{CXCR}^{+} / \mathrm{CXCR}^{-}{ }^{-}$Tfh cells $(\mathrm{r}=0.467, \mathrm{p}=0.016)$ (Fig. 3e and $\left.\mathrm{f}\right)$, but not with total Tfh $(\mathrm{r}=-$ 0.004, $\mathrm{p}=0.985$ ) and CXCR3- Tfh cells ( $\mathrm{r}=-0.435, \mathrm{p}=0.025)$ (Fig. 3g and $\mathrm{h}$ ). These findings indicate that $\mathrm{CXCR}^{+}$Tfh cells may play an important role in supporting or maintaining $\mathrm{nAb}$ responses in recovered COVID-19 individuals. Then, we proceeded to examine whether these $\mathrm{CXCR}^{+}$Tfh cells were SARS-CoV-2 spike-specific. We stimulated PBMCs from convalescents with both S1 and S2 (S1+S2) of SARS-CoV-2 spike and identified spike( $\mathrm{S} 1+\mathrm{S} 2)$-specific proliferation of $\mathrm{CD} 25^{+} \mathrm{OX} 40^{+} \mathrm{CXCR} 3^{+} \mathrm{Tfh}$ cells (Fig. 3i). We previously found a positive correlation between $\mathrm{CXCR}^{+} \mathrm{Tfh}$ cells with $\mathrm{HCV}$ nAb titer ${ }^{24}$. Similarly, $\mathrm{CXCR}^{+}{ }^{+} \mathrm{ICOS}^{+} \mathrm{CXCR}^{+} \mathrm{CD}^{+} \mathrm{T}$ cells ${ }^{25}$ and circulating Th1-biased helper cells ${ }^{26}$ were positively associated with influenza virus- and HIVspecific antibody responses, respectively. Together, we concluded that CXCR3 ${ }^{+} \mathrm{Tfh}$ cellcontribute to initiate and/or maintain nAbs in recovered COVID-19 individuals.

We have systematically investigated antibody responses in recovered COVID-19 individuals. Of 67 subjects, 97.01\% (65/67) elicited nAbs potently neutralized SARS- 
medRxiv preprint doi: https://doi.org/10.1101/2020.06.12.20129460; this version posted June 14, 2020. The copyright holder for this preprint

CoV-2 (Fig. 1d), of which some had cross-neutralization against SARS-CoV and/or MERS-CoV (Fig. 1f). Variations in cross-neutralization titers between these coronaviruses may be may explained, in part, by sequence homology of spike protein, in which SARS-CoV-2 spike shares $\sim 76 \%$ with SARS-CoV spike but only $24 \%$ with MERS-CoV spike ${ }^{27}$. Neutralization effects were supported by the endpoint titers and binding avidity against SARS-CoV-2, SARS-CoV, and MERS-CoV (Fig. 1a and b, Extend Data Table 3). nAbs in COVID-19 convalescents was reported but only for those with mild symptoms ${ }^{1,16}$. Cross-binding activity of COVID-19 sera was recently tested against SARS-CoV (spike and S1) and MERS-CoV spike, but only included 3 sera $^{28}$. Patient-derived SARS-CoV monoclonal and RBD-specific CR3022 antibodies could cross-neutralize SARS-CoV-2 29,30 , however low titer of SARS-CoV sera was found without cross-neutralization for SARS-CoV-2 ${ }^{17}$. Thus, low levels of nAbs may result in inefficient cross-neutralization. Indeed, antibody titers had positive correlation with neutralization activity (Extend Data Fig. 1a-c). SARS-CoV-2 spike (S1 and S2)-specific nAbs had endpoint titers up to $1: 10^{4.2-4.4}$ dilutions, which may account for the $97.01 \%$ neutralization to SARS-CoV-2, and $76.12 \%$ (65.67\% plus $10.45 \%)$ and $17.91 \%(7.46 \%$ plus $10.45 \%$ ) cross-neutralization to SARS-CoV and MERS-CoV, respectively (Fig. 1f). Cross-neutralization with MERS-CoV was most likely mediated by S2 binding only (Fig. 1c and Extend Data Table 3). Low cross-binding to MERS-CoV spike, but not S1, were recently described using 3 COVID-19 sera $^{28}$. Thus, some COVID-19 patients could elicit nAbs cross-neutralizing MERS-CoV. Interestingly, $10.45 \%$ sera cross-neutralized both SARS-CoV and MERS-CoV (Fig. 1f), supporting the cross-neutralization of MERS-CoV 
by $25 \%$ SARS-CoV srea ${ }^{31}$. Existence of cross-neutralizing antibodies offers a possibility to isolate or develop antibodies with neutralizing activity across different coronaviruses.

It is surprising that individuals recovered from severe COVID-19 elicited and maintained higher antibody and neutralization titers than non-severe group (Fig. 2), and the nAb titers positively correlated with severity of disease other than other factors (Table 1, Extend Data Table 1). Similar to what seen for recovered MERS-CoV patients, levels of nAbs positively associated with days in ICU, viral shedding, and ventilation need, several characteristics of critical conditions ${ }^{32}$. We found that SARS-CoV-2 convalescents exhibited low lymphocyte count during the course of disease, but with an accelerated increase, followed by a rebound after discharge (Fig. 2d-e). Rapidly increased lymphocyte counts may be responsible for the high levels of nAb. In recovered MERS$\mathrm{CoV}$ and SARS-CoV-2 patients, nAbs were correlated with antigen-specific $\mathrm{CD}^{+}{ }^{+} \mathrm{T}$ cells ${ }^{16,32}$, and $\mathrm{nAb}$ responses were more stable and longer in recovered severe MERSCoV patients ${ }^{33}$. Importantly, we found that levels of $\mathrm{CXCR}^{+} \mathrm{Tfh}^{\mathrm{T}}$ cells was significantly higher in recovered severe group than in non-severe group, correlated with $\mathrm{nAb}$ responses, and importantly were spike-specific (Fig. 2e-i). Correlations of $\mathrm{CXCR}^{+} \mathrm{Tfh}$ cells with $\mathrm{nAb}$ responses also exists in other virus infections, such as $\mathrm{HCV}^{24}$ and $\mathrm{HIV}^{26}$. Study on one non-severe COVID-19 patient showed that PD- ${ }^{+} \mathrm{ICOS}^{+}$Tfh cells progressively increased from day 7 after onset of illness ${ }^{34}$. Taken together, circulating CXCR3-biased Tfh cells increased rapidly in severe COVID-19 patients play a critical role in eliciting spike-specific antibodies, with neutralizing activity for SARS-CoV-2 and, to a less extent, for SARS-CoV and MERS-CoV. 
In conclusion, we demonstrated that majority of recovered COVID-19 individuals elicited and maintained robust $\mathrm{nAb}$ responses, of which some can cross-neutralize SARS$\mathrm{CoV}$ and/or MERS-CoV. The nAb responses are positively correlated with severity of disease and with spike-specific circulating $\mathrm{CXCR}^{+} \mathrm{Tfh}$ cells, which were more rapidly populated in recovered severe patients. Beyond this cross-sectional study, the longevity and affinity maturation of nAbs warrant future investigations. Our findings provide important evidence on humoral responses to SARS-CoV-2 infection.

\section{Acknowledgements}

We thank all of the participants. This work was supported by the Special Project for Novel Coronavirus of The First People's Hospital of Chenzhou (X.Q.) and by the SC1PHE-CORONAVIRUS-2020: Advancing knowledge for the clinical and public health response to the 2019-nCoV epidemic" from European Commission (CORONADX, no. 101003562) (Y.-P.L).

\section{Author contributions}

X.Q., W.L, Y.-P.L. and Y.W. contributed to the study design and data interpretation. Q.W., T.X., M.H., D.P., G.L., X.X., S.H., Y.D., J.L., W.L., Z.L., H.C., T.Z., Q.L., contributed to clinical management, patient recruitment, and data collection. J.Z., Q.W., Z.L., J.W., Y.H., T.B., T.W., W.H., K.J., L.N., W.G., D.L., Y.-P.L., contributed to samples processing, assays development, and experiments conduction. J.Z., Q.W., Z.L., T. W., D.L., and R.H. contributed to statistical analysis and data visualization. X.Q., P.L., Y.-P.L. and J.Z. drafted the manuscript. Y.W., X.Q. and Y.-P.L. contributed to critical revision of the manuscript for important intellectual contents. X.Q. and W.L. provided supervision. All authors meet authorship criteria and approve of publication. 


\section{Competing interests}

The authors declare no competing interests.

\section{References}

1. Wu, F., et al. Neutralizing antibody responses to SARS-CoV-2 in a COVID-19 recovered_patient cohort and their implications. (2020).

2. Zhu, N., et al. A Novel Coronavirus from Patients with Pneumonia in China, 2019. N Engl J Med 382, 727-733 (2020).

3. Zhou, P., et al. A pneumonia outbreak associated with a new coronavirus of probable bat origin. Nature 579, 270-273 (2020).

4. WHO. https://covid19.who.int/. (2020).

5. Guan, W.J., et al. Clinical Characteristics of Coronavirus Disease 2019 in China. N Engl J Med 382, 1708-1720 (2020).

6. $\mathrm{Hu}, \mathrm{Z}$., et al. Clinical characteristics of 24 asymptomatic infections with COVID19 screened among close contacts in Nanjing, China. Sci China Life Sci 63, 706$711(2020)$.

7. Shen, C., et al. Treatment of 5 Critically Ill Patients With COVID-19 With Convalescent Plasma. JAMA (2020).

8. Duan, K., et al. Effectiveness of convalescent plasma therapy in severe COVID19 patients. Proc Natl Acad Sci U S A 117, 9490-9496 (2020).

9. Wang, F., et al. The laboratory tests and host immunity of COVID-19 patients with different severity of illness. JCI Insight (2020).

10. Qin, C., et al. Dysregulation of immune response in patients with COVID-19 in Wuhan, China. Clin Infect Dis (2020).

11. Chen, G., et al. Clinical and immunological features of severe and moderate coronavirus disease 2019. J Clin Invest 130, 2620-2629 (2020). 
12. Fatima Amanat, et al. A serological assay to detect SARS-CoV-2 seroconversion in humans. (2020).

13. Guo, L., et al. Profiling Early Humoral Response to Diagnose Novel Coronavirus Disease (COVID-19). Clin Infect Dis (2020).

14. Zhao, J., et al. Antibody responses to SARS-CoV-2 in patients of novel coronavirus disease 2019. Clin Infect Dis (2020).

15. Long, Q.X., et al. Antibody responses to SARS-CoV-2 in patients with COVID19. Nat Med (2020).

16. Ni, L., et al. Detection of SARS-CoV-2-specific humoral and cellular immunity in COVID-19 convalescent individuals. Immunity (2020).

17. Anderson, D.E., et al. Lack of cross-neutralization by SARS patient sera towards SARS-CoV-2. Emerg Microbes Infect 9, 900-902 (2020).

18. Chen, X., et al. Human monoclonal antibodies block the binding of SARS-CoV-2 spike protein to angiotensin converting enzyme 2 receptor. Cell Mol Immunol (2020).

19. Rogers, T.F., et al. Rapid isolation of potent SARS-CoV-2 neutralizing antibodies and protection in a small animal model. (2020).

20. Ma, J., et al. Development of SARS and MERS Neutralization Methods Based on Pseudoviruses \% J Chinese Journal of Virology (In Chinese). 35, 189-195 (2019).

21. Morita, R., et al. Human blood CXCR5(+)CD4(+) T cells are counterparts of T follicular cells and contain specific subsets that differentially support antibody secretion. Immunity 34, 108-121 (2011).

22. Breitfeld, D., et al. Follicular B helper T cells express CXC chemokine receptor 5, localize to B cell follicles, and support immunoglobulin production. J Exp Med 192, 1545-1552 (2000).

23. Schaerli, P., et al. CXC chemokine receptor 5 expression defines follicular homing T cells with B cell helper function. J Exp Med 192, 1553-1562 (2000). 
24. Zhang, J., et al. Circulating CXCR3(+) Tfh cells positively correlate with neutralizing antibody responses in HCV-infected patients. Sci Rep 9, 10090 (2019).

25. Bentebibel, S.E., et al. Induction of ICOS+CXCR3+CXCR5+ TH cells correlates with antibody responses to influenza vaccination. Sci Transl Med 5, 176ra132 (2013).

26. Baiyegunhi, O., et al. Frequencies of Circulating Th1-Biased T Follicular Helper Cells in Acute HIV-1 Infection Correlate with the Development of HIV-Specific Antibody Responses and Lower Set Point Viral Load. J Virol 92(2018).

27. Wu, F., et al. A new coronavirus associated with human respiratory disease in China. Nature 579, 265-269 (2020).

28. Okba, N.M.A., et al. Severe Acute Respiratory Syndrome Coronavirus 2-Specific Antibody Responses in Coronavirus Disease 2019 Patients. Emerg Infect Dis 26(2020).

29. Wang, C., et al. A human monoclonal antibody blocking SARS-CoV-2 infection. Nat Commun 11, 2251 (2020).

30. Tian, X., et al. Potent binding of 2019 novel coronavirus spike protein by a SARS coronavirus-specific human monoclonal antibody. Emerg Microbes Infect 9, 382385 (2020).

31. Chan, K.H., et al. Cross-reactive antibodies in convalescent SARS patients' sera against the emerging novel human coronavirus EMC (2012) by both immunofluorescent and neutralizing antibody tests. J Infect 67, 130-140 (2013).

32. Zhao, J., et al. Recovery from the Middle East respiratory syndrome is associated with antibody and T-cell responses. Sci Immunol 2(2017).

33. Alshukairi, A.N., et al. Antibody Response and Disease Severity in Healthcare Worker MERS Survivors. Emerg Infect Dis 22(2016).

34. Thevarajan, I., et al. Breadth of concomitant immune responses prior to patient recovery: a case report of non-severe COVID-19. Nat Med 26, 453-455 (2020). 


\section{Figure legends}
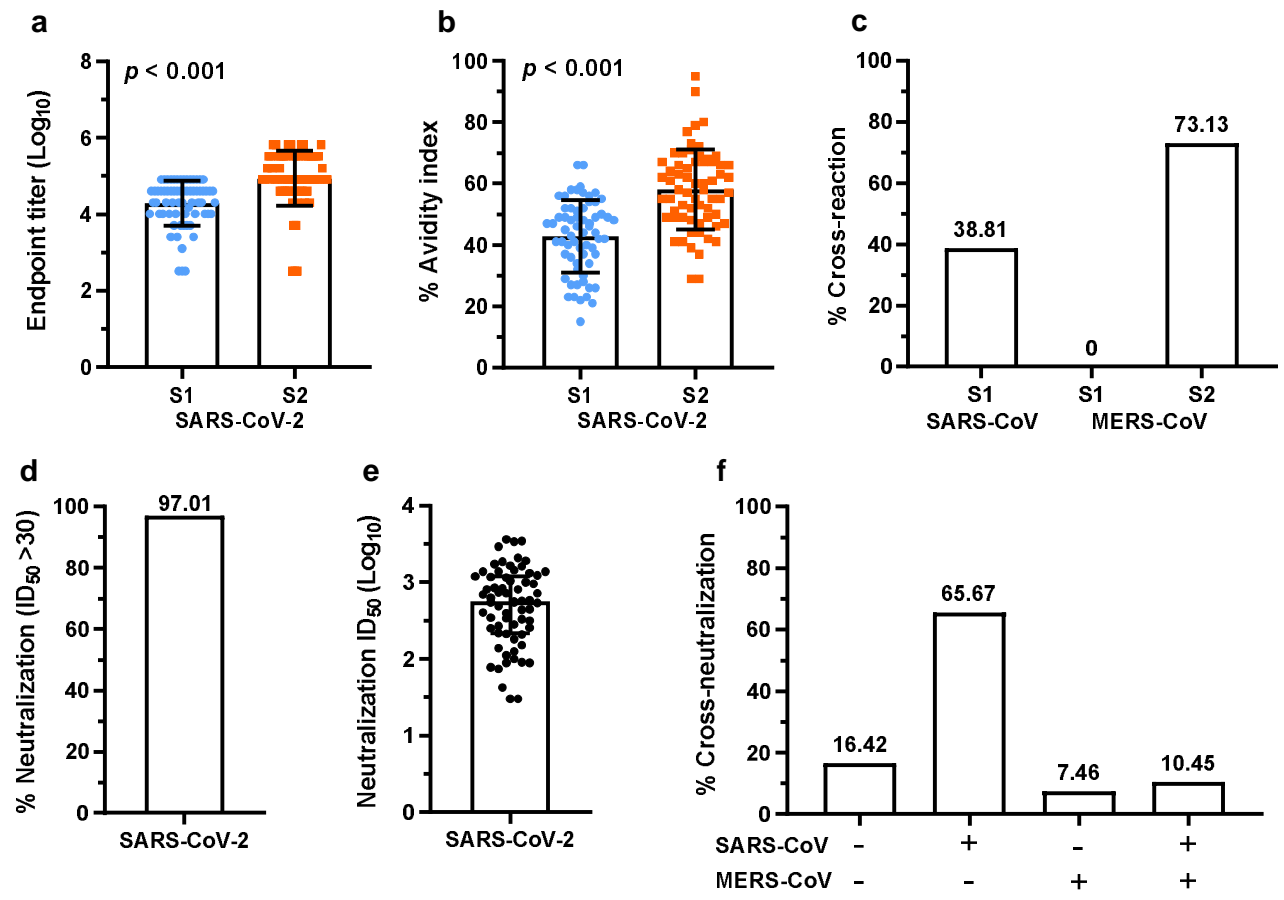

Fig. 1| Neutralizing antibody responses and cross-neutralization activity of serum IgG antibodies from recovered COVID-19 individuals. a, Endpoint titers of serum IgG antibodies from recovered COVID-19 individuals ( $\mathrm{n}=67)$ determined by binding to S1 and S2 subunits of SARS-CoV-2 spike protein; Binding to S2 was significantly higher than binding to S1. b, Avidity index of serum IgG antibody to S1 and S2 antigens of SARS-CoV-2 (n=64); S2 showed higher avidity. c, Percentage of COVID-19 convalescent sera cross-binding with S1 of SARS-CoV spike protein and S1 and S2 of MERS-CoV spike (total, $\mathrm{n}=67$ ). d, Percentage of sera with neutralizing $\mathrm{IgG}$ antibody 
against SARS-CoV-2 pseudovirus particles $(64 / 67, \mathrm{n}=67)$. e, Neutralizing titer of sera IgG antibody ( $\mathrm{n}=67)$ against SARS-CoV-2 pseudovirus particles $\left(\mathrm{ID}_{50}, \log _{10}\right) . \mathbf{f}$, Percentage of serum IgG antibodies ( $\mathrm{n}=67$ ) cross-neutralizing pesudoviruses of SARS$\mathrm{CoV}$ and MERS-CoV; plus "+" and minus “-” stand for positive and negative neutralization, respectively. Endpoint titer and neutralization titer were logarithmic transformed (a and e). Mann-Whitney U test was used to compare difference between two groups (a and $\mathbf{b}$ ), and adjusted $p$ value $<0.05$ was considered significant difference between groups. 

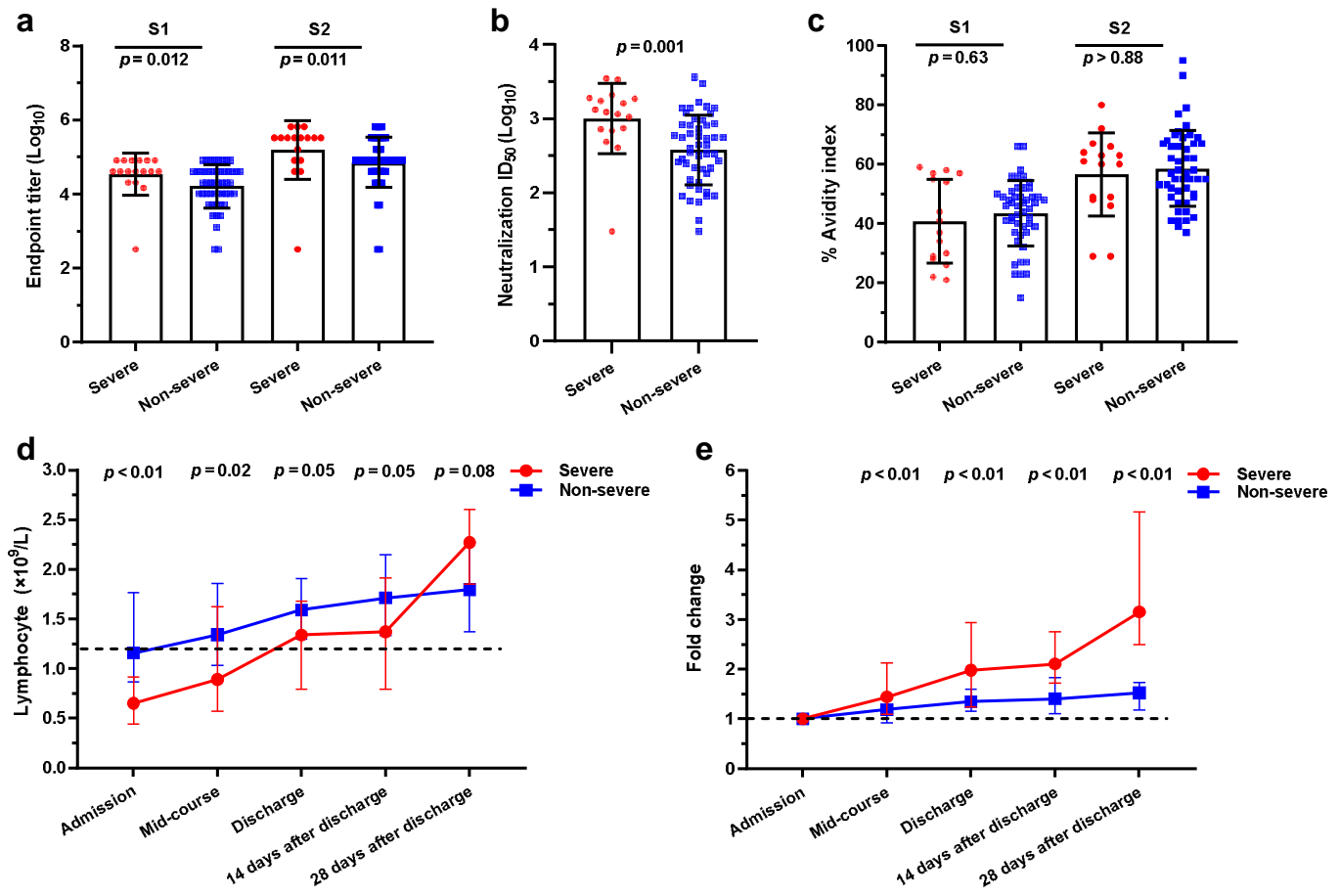

Fig. 2 | Distinct neutralizing antibody responses and lymphocyte kinetics between

\section{subjects recovered from severe and non-severe COVID-19.}

a, Endpoint titers of serum IgG antibodies specific to S1 and S2 of SARS-CoV-2 spike for severe ( $\mathrm{n}=17)$ and non-severe ( $\mathrm{n}=50)$ groups; severe group was significantly higher than non-severe group. $\mathbf{b}$, Neutralization titers of sera, from severe $(\mathrm{n}=17)$ and non-severe $(\mathrm{n}=50)$ groups, against SARS-CoV-2 pesudovirues; Titers of severe group was higher than non-severe group. c, Avidity of serum IgG antibodies to S1 and S2 of SARS-CoV-2 for severe ( $n=16)$ and non-severe groups $(n=48)$; no significant difference between two groups. d-e, Kinetics (d) and fold change (e) of lymphocyte count in severe (red line) and non-severe (blue line) groups; lymphocyte counts of severe group increased faster than non-severe group during the course of disease and after discharge; patient number 
included in data collection and analysis were the following (severe vs. non-severe): on admission (17 vs. 50), mid-course of disease (17 vs. 41), discharge (16 vs. 30), 14 days after discharge (13 vs. 40), and 28 days after discharge (13 vs. 40). Endpoint titers and neutralization titers were logarithmic transformed (a and b). Mann-Whitney U test was used to compared difference between two groups (a-e), and $p$ value $<0.05$ was considered significant difference between groups. 
a

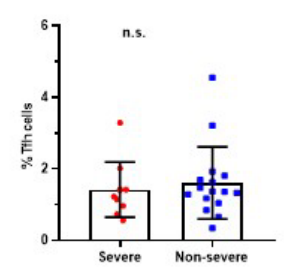

b

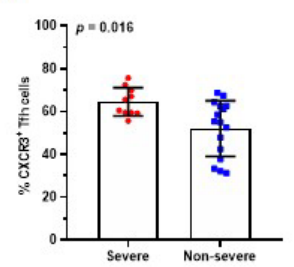

c

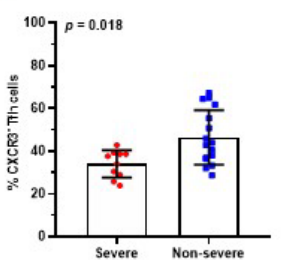

h
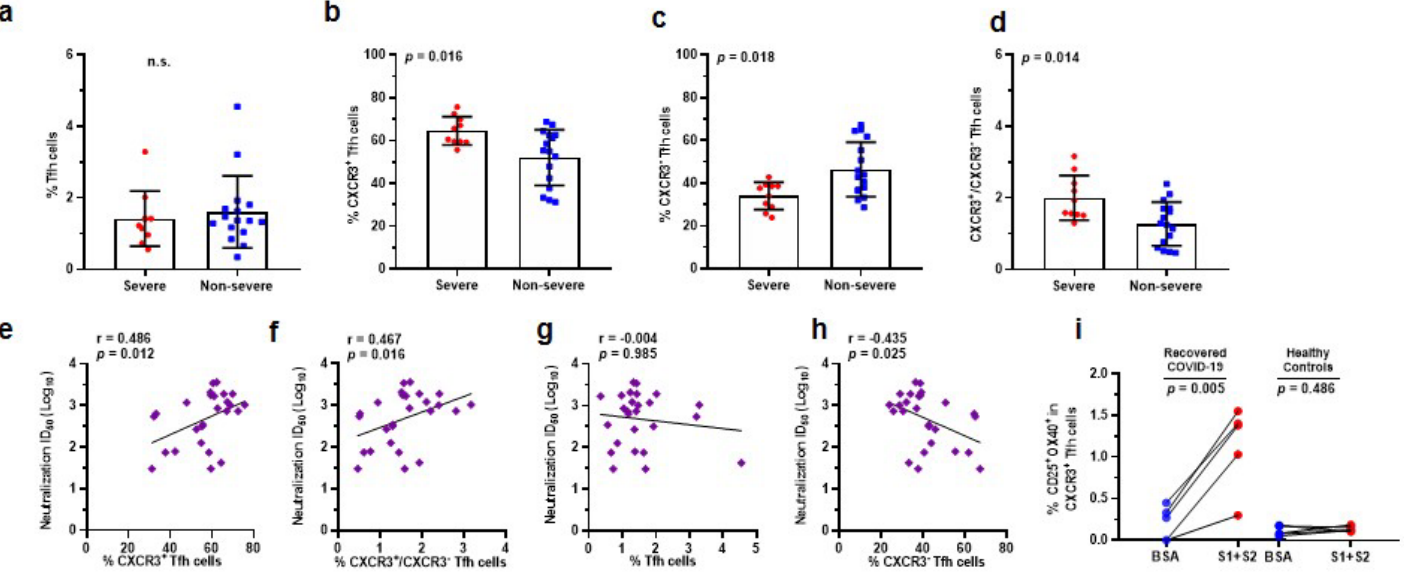

Fig. 3 | Neutralizing antibody titers were associated with frequencies of circulating $\mathrm{CXCR3}^{+}{ }^{\text {Tfh }}$ cells in recovered COVID-19 individuals.

a-d, Frequencies of circulating Tfh cells (Tfh) (a), $\mathrm{CXCR}^{+}$and $\mathrm{CXCR} 3^{-} \mathrm{Tfh}$ subsets (b, c), and ratio of $\mathrm{CXCR}^{+} / \mathrm{CXCR}^{-} \mathrm{Tfh}$ cells $(\mathbf{d})$ in severe $(\mathrm{n}=10)$ and non-severe $(\mathrm{n}=16)$ groups; severe group had a high level of CXCR3 ${ }^{+}$Tfh cells. e-h, Correlation analyses of serum neutralization titers and frequencies of $\mathrm{CXCR}^{+} \mathrm{Tfh}$ cells $(\mathbf{e})$, ratio of $\mathrm{CXCR}^{+} / \mathrm{CXCR}^{-}{ }^{-}$Tfh cells $(\mathbf{f})$, total Tfh cell cells $(\mathbf{g})$, and CXCR3 ${ }^{-}$Tfh subsets $(\mathbf{h})$ in recovered COVID-19 individuals $(\mathrm{n}=26)$. $\mathbf{i}$, Spike-specific circulating Tfh cell response after antigen stimulation. PBMCs from recovered individuals $(\mathrm{n}=5)$ and healthy controls $(\mathrm{n}=5)$ were stimulated with both $\mathrm{S} 1$ and $\mathrm{S} 2$ proteins $(\mathrm{S} 1+\mathrm{S} 2)$ for 24 hours, antigenspecific $\mathrm{Tfh}\left(\mathrm{OX} 40^{+} \mathrm{CD} 25^{+} \mathrm{CXCR} 3^{+} \mathrm{Tfh}\right)$ cells were analyzed by flow cytometry. Neutralization titers were logarithmic transformed (e-h). Mann-Whitney U test was used to compared difference between two groups (a-d), Paired t test was used to compared difference between two groups (i). Spearman's rank correlation coefficient was used to describe the relationship between neutralization titers and frequencies of Tfh cells and subsets (e-h). $p$ value $<0.05$ was considered significant difference between groups. 


\section{Tables}

\section{Table 1. Univariate and multivariable analyses for factor association with neutralizing antibody responses $(\mathrm{OR}, 95 \% \mathrm{CI})$}

Data expressed as Odds ratios (OR) and 95\% two-sided confidence interval (95\% CI). Univariate and Multivariable Binary Logistic Regression models were used to evaluate the influence factors for neutralizing antibody. The median of cutoff dependent variable value $\left(\mathrm{ID}_{50}, \log _{10}\right)$ for neutralization were set at 2.41 , thus the estimated probability of $<2.41$ was classified as low neutralization ability group, and a probability of $>2.41$ was classified as high neutralization ability group. All of covariates were classified by median and changed to two categories of variables for Logistic Regression analysis. Course of disease was defined as the duration (days) from disease onset to discharge.

Table 1 Analysis of impact factors on neutralization antibody (OR, 95\% CI)

\begin{tabular}{|c|c|c|c|}
\hline Analysis & Univariate (OR, 95\% CI) & Multivariable (OR, 95\% CI) \\
\hline Course of disease & $3.67(1.34-10.06)$ & $2.14(0.67-6.78)$ \\
\hline Disease of Severity & $7.00(1.78-27.53)$ & $5.04(1.003-25.3)$ \\
\hline Comorbidities & $3.33(1.2-9.29)$ & $0.43(0.13-1.42)$ \\
\hline Underlying disease & $2.78(0.98-7.88)$ & $0.77(0.19-3.17)$ \\
\hline
\end{tabular}




\section{Methods}

\section{Patients and sample collection}

Total 67 recovered COVID-19 patients were enrolled in this study, and diagnosis of COVID-19 was performed according to WHO interim guidance. All of patients came to outpatient showed fever or respiratory symptoms. Chest computed tomography (CT) scans identified abnormal pulmonary nodules, and SARS-CoV-2 infection was further confirmed using real-time PCR by the local health authority. All of patients were hospitalized in Department of Infectious Disease, The Centre Hospital of Shaoyang, Hunan province, China, from January 23 to March 2, 2020. The severity of COVID-19 was graded according to the Chinese Management Guideline for COVID-19 (version 6.0). Of 67 patients, 17 were categorized in severe conditions, and 50 were in mild to moderate symptoms (refer to as non-severe in this study). The medical history and the results of physical, hematological, biochemical, radiological, and microbiological analyses were retrospectively evaluated and analyzed. Peripheral blood of the recovered individuals was collected on day 28 after discharge, corresponding to 44 to 52 days after symptom onset. Peripheral blood mononuclear cells (PBMCs) and serum were isolated and frozen in liquid nitrogen at $-80^{\circ} \mathrm{C}$ ultra-low temperature freezers, respectively.

\section{Antibody endpoint titer assay}

The endpoint titer of antibody was determined by measuring the binding index of serum with S1 and S2 subunits of SARS-CoV-2 spike protein using enzyme linked immunosorbent assay (ELISA). In brief, 96-well plates (Corning, NY, USA) were coated with $20 \mathrm{ng} /$ well $\mathrm{S} 1$ or S2 subunit proteins in PBS overnight at $4{ }^{\circ} \mathrm{C}$. Plates were washed with $0.05 \%$ Tween-20 in PBS (PBS-T) for 5 times and then blocked with blocking buffer 
medRxiv preprint doi: https://doi.org/10.1101/2020.06.12.20129460; this version posted June 14, 2020. The copyright holder for this preprint (which was not certified by peer review) is the author/funder, who has granted medRxiv a license to display the preprint in perpetuity.

All rights reserved. No reuse allowed without permission.

(2\% FBS and 2\% BSA in PBS-T) for 30 minutes. Two-fold serial dilutions, started from 1:20 dilution, were added to the plate in triplicate $(100 \mu 1 /$ well $)$ and incubated for 1 hour at room temperature. Spike subunits S1- and S2-specific antibodies were detected by using horseradish peroxidase (HRP)-conjugated anti-human IgG and 3,3',5,5'tetramethylbenzidine substrate (Thermo Fisher Scientific, Waltham, MA, USA). Healthy sera were used as negative controls, and monoclonal antibody specific for the receptor binding domain (RBD) of SARS-CoV-2 spike protein (anti-RBD/SARS-CoV-2; made in the lab, unpublished data) was used as positive control. Optical density at $450 \mathrm{~nm}$ (OD450) was acquired for each reaction, and the OD450 being 3-fold above the cutoffOD450 value was considered to be positive. Serum cross-reactivity with S1 of SARS$\mathrm{CoV}$ as well as with both $\mathrm{S} 1$ and $\mathrm{S} 2$ of MERS-CoV were examined using an optimized serum dilution (1:1000). All of proteins (S1 and S2 of SARS-CoV-2; S1 of SARS-CoV; S1 and S2 of MERS-CoV) were purchased (Sino Biological, China).

\section{Antibody avidity assay}

IgG antibody avidity with $\mathrm{S} 1$ and $\mathrm{S} 2$ subunits from SARS-CoV-2 were measured by a modified 2-step approach described elsewhere ${ }^{1,2}$. In the first step, serum dilutions were optimized to have an OD450 value between 0.5 and 1.5 , so that it could ensure a linear measurement of avidity in next step. The second step was an ELISA assay but included an elution procedure of $1 \mathrm{M}$ NaSCN. The avidity index of antibody was calculated as OD NaSCN 1M/OD NaSCN $0 M \times 100 \%$.

\section{Antibody neutralization assay}

Neutralizing activity of sera was determined by the reduction in luciferase expression, as described previously for the HIV pseudovirus neutralization assay ${ }^{3}$. The $50 \%$ inhibitory 
dilution (ID50) was defined as the serum dilution, at which the relative light units (RLUs) were reduced by $50 \%$ compared with the control wells without serum. Background RLUs in the control groups were subtracted from all wells. In brief, pseudovirus were incubated with serial dilutions of sera samples (six dilutions $1: 30 ; 1 ; 90 ; 1: 270 ; 1: 810 ; 1: 2430$; 1:7290) in duplicate at $37^{\circ} \mathrm{C}$ for 1 hour. The control wells were included in duplicate. Naïve Huh7 cells were added to each well and incubated in $5 \% \mathrm{CO}_{2}$ at $37^{\circ} \mathrm{C}$ for 24 hours. The luminescence was measured, and the $\mathrm{ID}_{50}$ values were calculated with non-linear regression, i.e. $\log$ (inhibitor) vs. response (four parameters), using GraphPad Prism 8 (GraphPad Software, Inc., San Diego, CA, USA). Cross-neutralization with SARS-CoV and MERS-CoV were determined using same methods.

\section{Autoantibody detection}

Two milliliters of blood were collected from the participants using EDTA anticoagulation tubes (BD Biosciences, Franklin Lake, NJ, USA), and sera were immediately isolated by centrifugation $(3,000 \mathrm{rpm})$ for 5 minutes (Sorvall ST 40R Centrifuge, Thermo Fisher Scientific). Sixteen autoimmune antibodies were tested to examine whether the autoimmunity occurred after recovery from SARS-CoV-2 infection. Of which, antidsDNA and anti-ANA antibodies were detected by ELISA (Zeus Scientific, Inc. New Jersey, USA), while anti-nucleosomes, histones, SmD1, U1-SnRNP, SS-A/Ro60KD, SSA/Ro52 KD, SS-B/La, Sc1-70, CENP-B, Jo-1, and anti-PO/38KD were examined by Line Immuno Assay (LIA), according to the manufacturer's protocols (HUMAN GmbH, Magdeburg, Germany). 
medRxiv preprint doi: https://doi.org/10.1101/2020.06.12.20129460; this version posted June 14, 2020. The copyright holder for this preprint (which was not certified by peer review) is the author/funder, who has granted medRxiv a license to display the preprint in perpetuity.

All rights reserved. No reuse allowed without permission.

\section{Flow cytometry}

Ten milliliters of blood were collected from recovered COVID-19 patients and heathy volunteers with EDTA anticoagulant tubes (BD Biosciences). PBMCs were immediately isolated by Ficoll density gradient centrifugation, according to the manufacturer's protocol (GE Healthcare Bio-Sciences AB, Kontaktuppgifter, Sweden), and stored in liquid nitrogen using a programmed cooling procedure.

To analyze the circulating follicular helper T cells (Tfh) and Tfh subsets, cryopreserved PBMCs were thawed at $37^{\circ} \mathrm{C}$ water bath and cultured immediately in RPMI 1640 medium supplemented with $10 \%$ FBS overnight in $5 \% \mathrm{CO} 2$ at $37^{\circ} \mathrm{C}$. For cell surface staining, $1 \times 10^{6} \mathrm{PBMCs} / \mathrm{mL}$ were first labeled with a LIVE/DEAD® Fixable Blue Dead Cell Stain Kit (Thermo Fisher Scientific) to exclude dead cells, and then treated with Fc Block (BioLegend, San Diego, CA, USA) to block non-specific binding. The treated PBMCs were stained with antibodies, which had been pre-titrated and fluorescently labeled, in 96-well V-bottom plates at $4{ }^{\circ} \mathrm{C}$ for 30 minutes. The fluorescently labeled antibodies used in this study were BUV737 mouse anti-human CD4 (SK3) and PE mouse anti-human CXCR3 (1C6) (BD Biosciences), FITC mouse anti-human PD-1 (EH12.2H7) (BioLegend), and PE-eFluor 610 mouse anti-human CXCR5 (MU5UBEE) (Thermo Fisher Scientific, Waltham, MA, USA). Cell population gating was set based on the mean fluorescence intensity "minus one" (FMO) and unstained controls. Samples were loaded onto a MoFlo XDP Flow Cytometer (Beckman Coulter, Brea, CA, USA) immediately after antibody staining. All data were analyzed with FlowJo 10.0 software (Tree Star, San Carlos, CA, USA). 


\section{Antigen-specific Tfh cell assay}

Cryopreserved PBMCs were thawed and cultured in complete RPMI1640 medium in 5\% $\mathrm{CO} 2$ at $37^{\circ} \mathrm{C}$ incubator overnight. Cells were stimulated with SARS-CoV-2 spike protein (S1 plus S2) $(5 \mu \mathrm{g} / \mathrm{mL})$ or negative control BSA $(5 \mu \mathrm{g} / \mathrm{mL})$ (Sigma-Aldrich, St. Louis, MO, USA) in $5 \% \mathrm{CO} 2$ at $37^{\circ} \mathrm{C}$ for 24 hours. PBMCs from healthy controls were included in parallel as controls. Circulating Tfh (cTfh) cells were gated as live CD4 ${ }^{+} \mathrm{PD}-1^{+} \mathrm{CXCR} 5^{+}$ T cells. PE-Cy ${ }^{\mathrm{TM}} 5$ mouse anti-human CD25 (M-A251) (BD Biosciences) and APC mouse anti-human OX40 (ACT35) (BioLegend) were used to define antigen-specific $\left(\mathrm{CD} 25^{+} \mathrm{OX} 40^{+}\right)$Tfh cell responses after stimulation as described previously ${ }^{4,5}$.

\section{Statistical analysis}

Baseline clinical characteristics data were non normal distribution, so continuous variables were expressed as median and Interquartile Range (IQR). Rank variables was expressed as constituent ratio. Mann-Whitney U test and $\chi^{2}$ or Fisher's Exact tests were used in the comparison of two different groups. Paired Sample t test was used to compare the antigen-specific Tfh cells before and after the stimulation with S1 and S2 proteins. Kruskal-Wallis test was used for the comparison of multiple groups, and Dunn's multiple comparisons test was used between two groups. Spearman's Rank Correlation Coefficient was used to measure the correlation between two variables of Tfh cells, neutralization antibodies, and binding avidity. Univariate and Multivariable Binary Logistic Regression model was used to rank the factors potential associations with nAb responses. Odds ratios (ORs) and 95\% two-sided confidence interval (95\% CI) were generalized by equation models to describe the factors contributing to $\mathrm{nAb}$ responses. Analyses of the data were done by SPSS version 26 and GraphPad Prism version 8.0. 


\section{Ethics approval}

This study was performed in accordance with the Good Clinical Practice and the

Declaration of Helsinki principles for ethical research. The study protocol was approved by the Institutional Review Board of The Center Hospital of Shaoyang (V1. 0, 20200301), Hunan Province, China. Written informed consent was obtained from each participant. Medical data were collected from electronic records of the hospitals using standardized Data Collection Forms recommended by the International Severe Acute Respiratory and Emerging Infection Consortium.

\section{Reference}

1. Ray, R., et al. Characterization of antibodies induced by vaccination with hepatitis C virus envelope glycoproteins. J Infect Dis 202, 862-866 (2010).

2. $\quad$ Welten, S.P.M., Redeker, A., Toes, R.E.M. \& Arens, R. Viral Persistence Induces Antibody Inflation without Altering Antibody Avidity. J Virol 90, 4402-4411 (2016).

3. Chen, Q., et al. Development and optimization of a sensitive pseudovirus-based assay for HIV-1 neutralizing antibodies detection using A3R5 cells. Hum Vaccin Immunother 14, 199-208 (2018).

4. Haltaufderhyde, K., et al. Activation of Peripheral T Follicular Helper Cells During Acute Dengue Virus Infection. J Infect Dis 218, 1675-1685 (2018).

5. Dan, J.M., et al. A Cytokine-Independent Approach To Identify Antigen-Specific Human Germinal Center T Follicular Helper Cells and Rare Antigen-Specific CD4+ T Cells in Blood. J Immunol 197, 983-993 (2016). 


\section{Extend Data Figures and Tables}
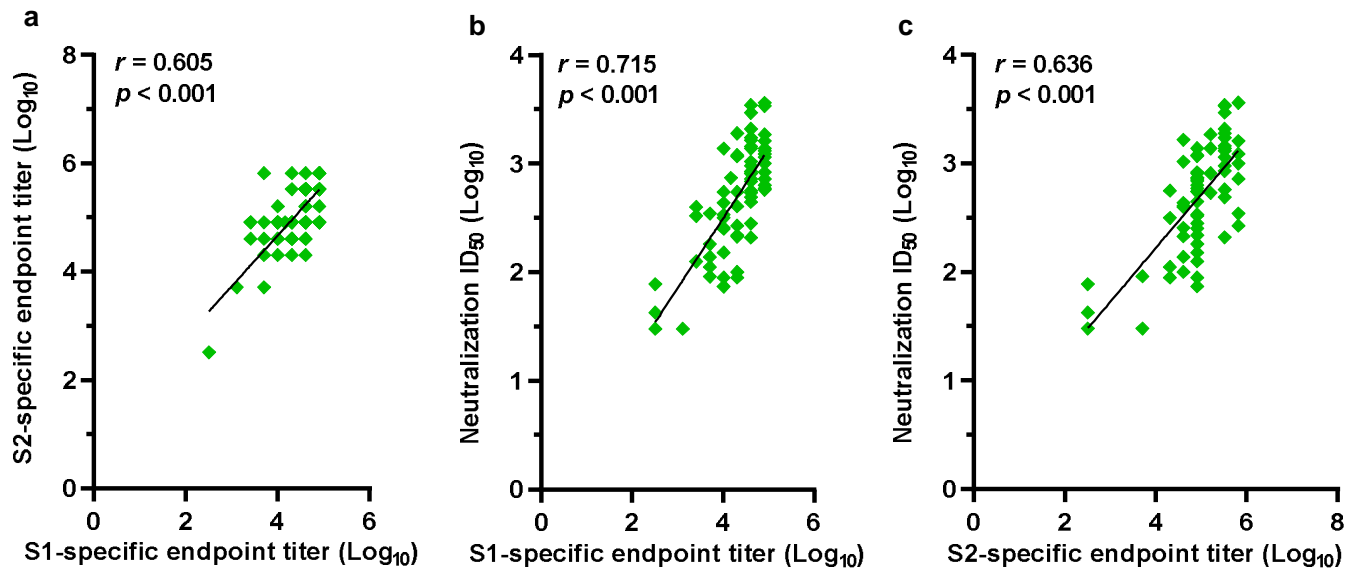

\section{Extend Data Figure 1. Correlation analysis of the serum neutralization titers and the endpoint titers of anti-S1 and anti-S2 antibodies.}

Correlation analysis was performed, using Spearman's rank coefficient of correlation, to identify the strength of relationships between neutralization titers of serum antibodies against SARS-CoV-2 pesudovirus and the endpoint titers (binding activity) of antibodies binding to S1 and S2 subunits of SARS-CoV-2. Correlation between S1- and S2-specific endpoint titers of serum antibodies (a), sera neutralization titers and S1-specific endpoint titers (b), and sera neutralization titers and S2-specific endpoint titers (c); Positive correlations existed between S1- and S2-specific endpoint titers as well as between neutralization and S1- or S2-specific endpoint titers. $p$ value $<0.05$ was considered to be significantly different between groups. 


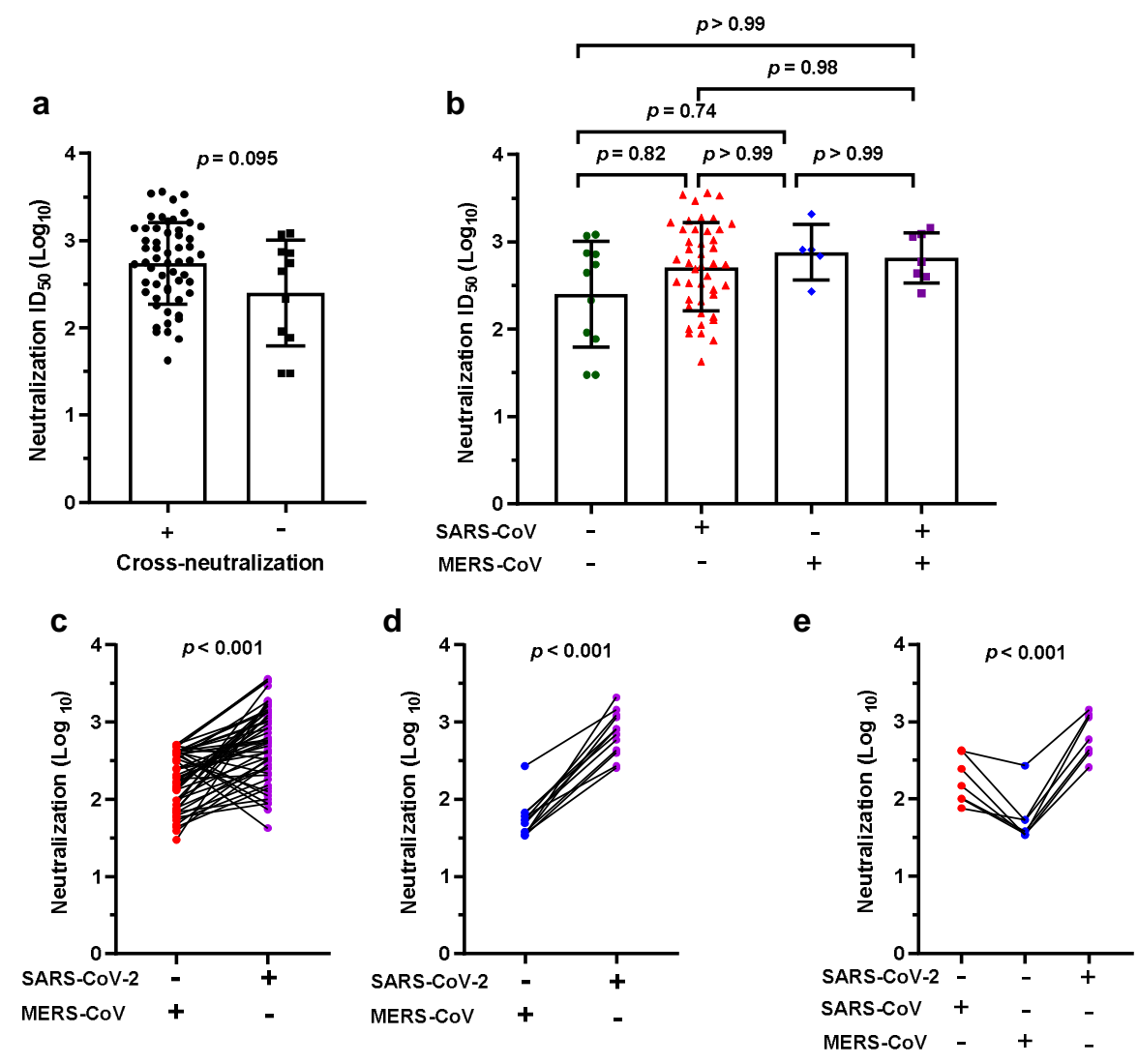

Extend Data Figure 2. Neutralization titers of SARS-CoV-2 pesudovirus for the serum IgG antibodies that had cross-neutralization with SARS-CoV and MERSCoV.

a. Serum neutralizing titers against SARS-CoV-2 pesudovirus were divided into two groups, with and without cross-neutralization activity against SARS-CoV and/or MERS$\mathrm{CoV}$; No difference between two groups. b. Comparison of SARS-CoV-2-specific neutralizing titers of the sera with cross-neutralization with SARS-CoV and/or MERS$\mathrm{CoV}$; No difference between two groups. c-e. Comparison of neutralization titers for 
medRxiv preprint doi: https://doi.org/10.1101/2020.06.12.20129460; this version posted June 14, 2020. The copyright holder for this preprint (which was not certified by peer review) is the author/funder, who has granted medRxiv a license to display the preprint in perpetuity.

All rights reserved. No reuse allowed without permission.

SARS-CoV-2 and cross-neutralization titers for SARS-CoV, or for MERS-CoV, for individual COVID-19 convalescent serum; cross-neutralization titers for SARS-CoV or MERS-CoV were lower than that for SARS-CoV-2. 


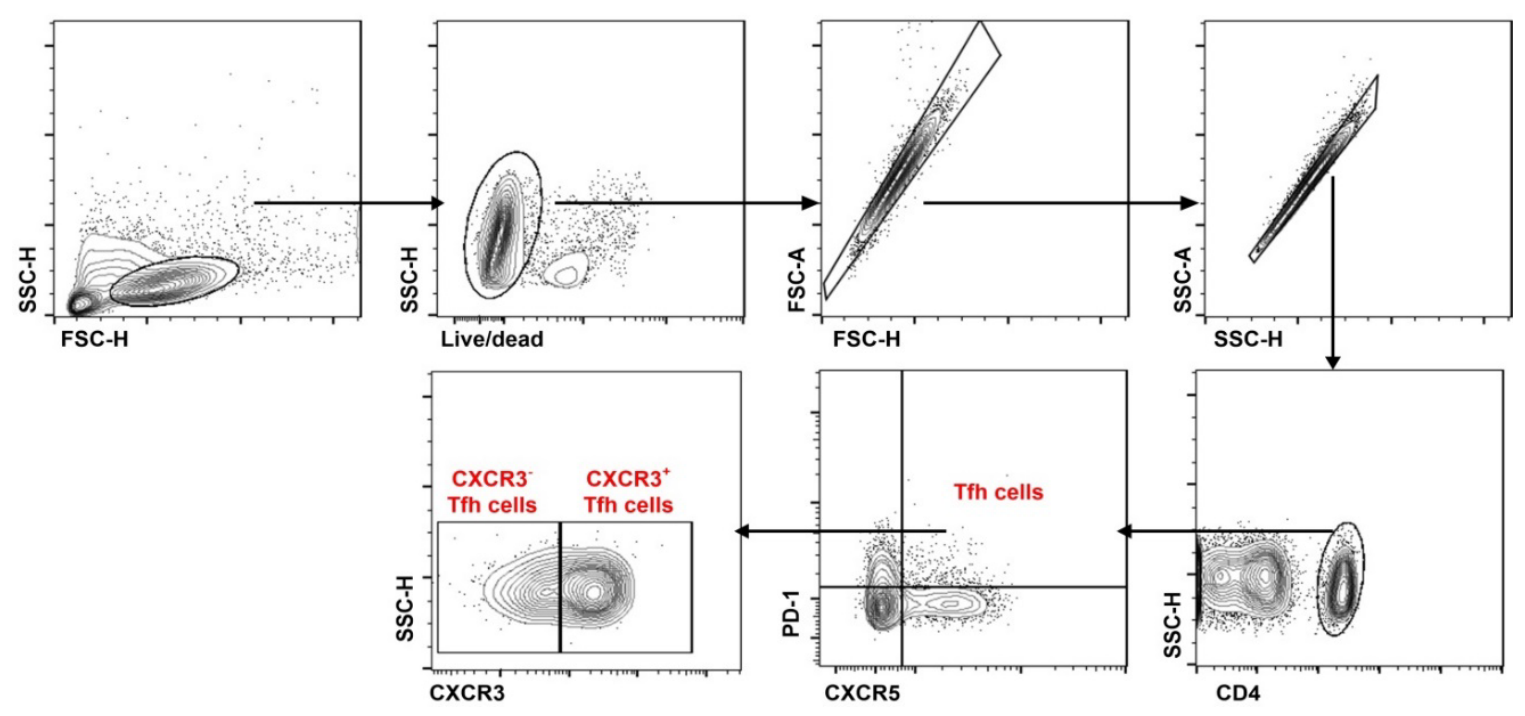

Extend Data Figure 3. Gating strategy of circulating Tfh cells in recovered COVID-

19 individuals. Representative gating strategy for circulating Tfh cells, CXCR $3^{+}$and CXCR $^{-}$Tfh cells in the flow cytometry analysis. Gating was based on the mean fluorescence intensity "minus one" (FMO). 


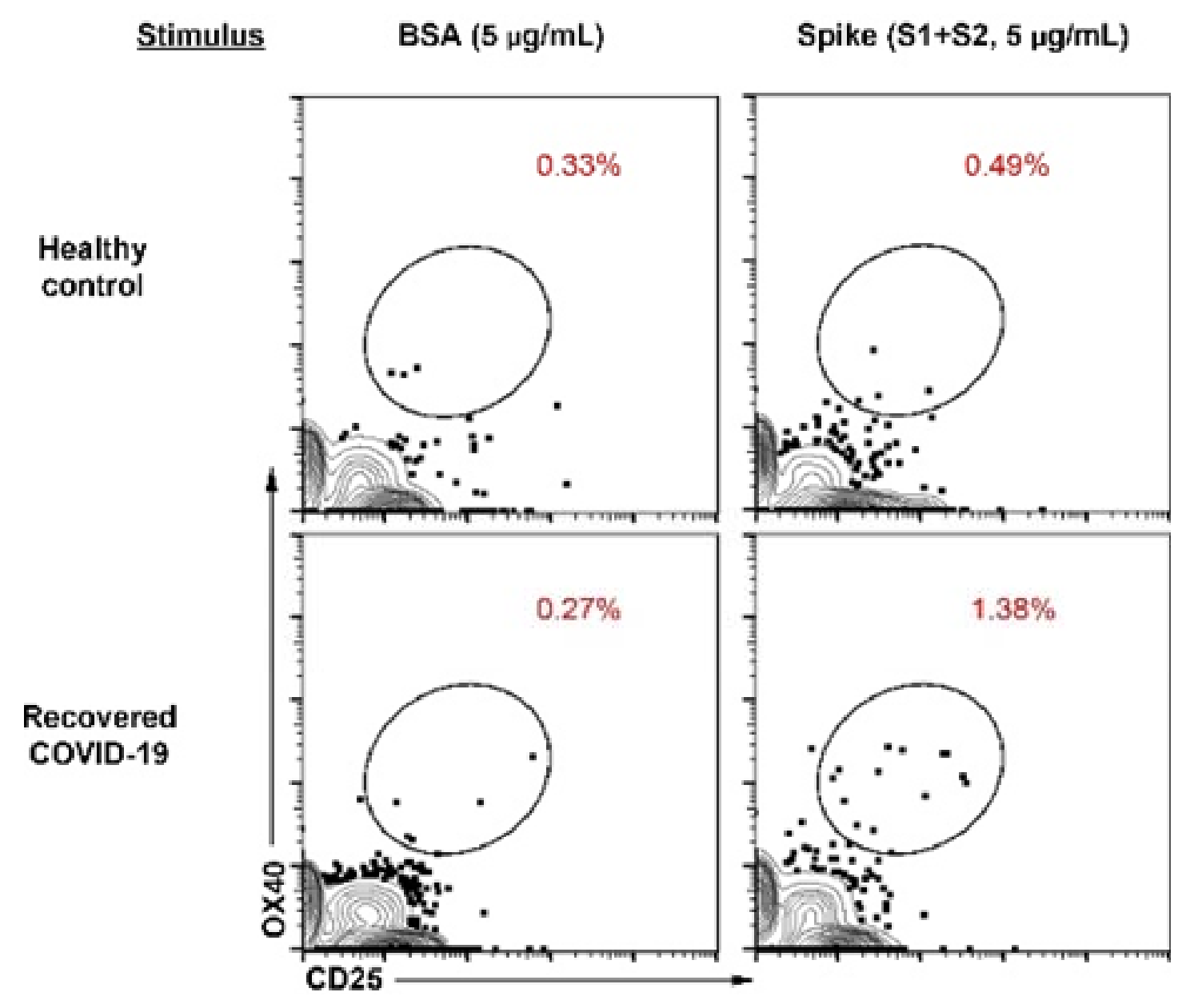

Extend Data Figure 4. Spike -specific Tfh cell responses after antigen stimulation in vitro.

Representative flow cytometry plots for the spike antigen-specific CXCR3 ${ }^{+} \mathrm{Tfh}$ cell $\left(\mathrm{CD} 25^{+} \mathrm{OX}_{40}{ }^{+} \mathrm{CXCR}^{+} \mathrm{Tfh}\right.$ cells $)$ responses from healthy control and recovered COVID-19 individuals. Gating was based on the mean fluorescence intensity "minus one" (FMO). PBMCs were stimulated with S1 plus S2 subunits $(5 \mu \mathrm{g} / \mathrm{mL})$ of SARS-CoV-2 spike protein in $5 \% \mathrm{CO} 2$ at $37^{\circ} \mathrm{C}$ for 24 hours. Cells stimulated with BSA $(5 \mu \mathrm{g} / \mathrm{mL})$ were negative control. 


\section{Extend Tables}

\begin{tabular}{|c|c|c|c|c|}
\hline \multicolumn{5}{|c|}{ Extend Data | Table 1. Baseline characteristics of COVID-19 patients recruited in this study } \\
\hline \multicolumn{5}{|c|}{ No $(\%)$} \\
\hline & Total $(n=67)$ & Severe $(\mathrm{n}=17)$ & Non-severe $(\mathbf{n}=50)$ & $P$ value \\
\hline \multicolumn{5}{|l|}{ Basic Information } \\
\hline Age (years) (IQR) & $43(30-53)$ & $59(45-69.5)$ & $41(29-47)$ & $<0.001^{*}$ \\
\hline \multicolumn{5}{|l|}{ Sex } \\
\hline Male & $34(50.8)$ & $11(64.7)$ & $23(46)$ & \multirow{2}{*}{0.26} \\
\hline Female & $33(49.3)$ & $6(35.3)$ & $27(54)$ & \\
\hline Course of disease (days) (IQR) & $20(16-25)$ & $25(21-28)$ & $18(16-23.3)$ & $0.007^{*}$ \\
\hline \multicolumn{5}{|l|}{ Presenting symptoms and signs } \\
\hline Cough & $59(88.1)$ & $17(100)$ & $42(84)$ & 0.10 \\
\hline Fever & $58(86.6)$ & $17(100)$ & $41(82)$ & 0.10 \\
\hline Fatigue & $41(61.2)$ & $12(70.6)$ & $29(58)$ & 0.40 \\
\hline Expectoration & $28(41.8)$ & $12(70.6)$ & $16(32)$ & $0.009^{*}$ \\
\hline Dyspnea & $26(38.8)$ & $15(88.2)$ & $11(22)$ & $<0.001^{*}$ \\
\hline Myalgia & $26(38.8)$ & $6(35.3)$ & $20(40)$ & 0.78 \\
\hline Chills & $21(31.3)$ & $12(70.6)$ & $9(18)$ & $<0.001^{*}$ \\
\hline Headache & $16(23.9)$ & $5(29.4)$ & $11(22)$ & 0.53 \\
\hline Anhelation & 10(14.9) & $5(29.4)$ & $5(10)$ & 0.11 \\
\hline Diarrhea & $5(7.5)$ & $2(11.8)$ & $3(6)$ & 0.60 \\
\hline Maximum body temperature (回) (IQR) & $38.3(37.7-38.7)$ & $38.5(38-39.1)$ & $38.3(37.5-38.5)$ & 0.054 \\
\hline \multicolumn{5}{|l|}{ Underlying disease } \\
\hline Cardiovascular diseases & $16(23.9)$ & $9(52.9)$ & $7(14)$ & $0.002^{*}$ \\
\hline Hypertension & $13(19.4)$ & $8(47.1)$ & $5(10)$ & $0.002^{*}$ \\
\hline Diabetes & $9(13.4)$ & $6(35.3)$ & $3(6)$ & $0.006^{*}$ \\
\hline COPD & $4(6)$ & $3(17.7)$ & $1(2)$ & $0.047^{*}$ \\
\hline HBV & $3(4.5)$ & $1(5.9)$ & $2(4)$ & $>0.99$ \\
\hline Total underlying disease & $24(35.8)$ & $13(76.5)$ & $11(22)$ & $<0.001$ \\
\hline \multicolumn{5}{|l|}{ Comorbidities } \\
\hline Liver insufficiency & $29(43.3)$ & $13(76.5)$ & $16(32)$ & $0.002^{*}$ \\
\hline Cardiac insufficiency & $25(37.3)$ & $9(52.9)$ & $16(32)$ & 0.15 \\
\hline Renal insufficiency & $4(6)$ & $2(11.8)$ & $2(4)$ & 0.27 \\
\hline Total Comorbidities & $29(43.28)$ & $14(82.4)$ & $26(52)$ & 0.044 \\
\hline
\end{tabular}


medRxiv preprint doi: https://doi.org/10.1101/2020.06.12.20129460; this version posted June 14, 2020. The copyright holder for this preprint (which was not certified by peer review) is the author/funder, who has granted medRxiv a license to display the preprint in perpetuity. All rights reserved. No reuse allowed without permission.

\section{Extend Data | Table 2. Laboratory findings of patients with COVID-19 on admission}

\begin{tabular}{|c|c|c|c|c|c|}
\hline \multicolumn{6}{|c|}{ Median (IQR) } \\
\hline & Normal range & Total $(n=67)$ & Severe $(n=17)$ & Non-severe $(\mathrm{n}=50)$ & $P$ value \\
\hline \multicolumn{6}{|l|}{ Blood routine } \\
\hline White blood cell count $\left(\times 10^{9} \mathrm{Gl}^{-1}\right)$ & $4-10$ & $5.4(4.2-8.7)$ & $5.4(4.1-11.3)$ & $5.4(4.1-8.1)$ & 0.41 \\
\hline Red blood cell count $\left(\times 10^{9} \mathrm{I}^{-1}\right)$ & $3.5-5$ & $4.7(4.2-5.1)$ & $4.7(4.1-5.2)$ & $4.8(4.2-5.1)$ & 0.49 \\
\hline Neutrophil count $\left(\times 10^{9} l^{-1}\right)$ & $1.4-7$ & $3.7(2.5-6.9)$ & $4.7(2.7-8.7)$ & $3.7(2.3-5.9)$ & 0.08 \\
\hline Neutrophil percentage (\%) & $45-75$ & $66(56.9-77)$ & $63.9(60.2-76.4)$ & $66.5(55.9-77.4)$ & 0.83 \\
\hline Lymphocyte count $\left(\times 10^{9} l^{-1}\right)$ & $1.2-3.5$ & $1(0.7-1.7)$ & $0.7(0.4-0.9)$ & $1.2(0.9-1.8)$ & $<0.001^{*}$ \\
\hline Lymphocyte percentage (\%) & $20-40$ & 23(14.1-31.7) & $24.9(13.5-28.3)$ & $22.6(14.5-33.9)$ & 0.67 \\
\hline Monocyte count $\left(\times 10^{9} \mathrm{l}^{-1}\right)$ & $0.1-1.2$ & $0.53(0.38-0.63)$ & $0.49(0.29-0.66)$ & $0.54(0.39-0.62)$ & 0.92 \\
\hline Monocyte percentage (\%) & $3-12$ & $8.5(6.5-11.1)$ & $8.9(6.9-12.3)$ & $8.4(6.5-10.9)$ & 0.35 \\
\hline Platelet count $\left(\times 10^{9} \mathrm{l}^{-1}\right)$ & $125-350$ & $223(154-258)$ & $154(133-191)$ & $234.5(187-270.8)$ & $0.001^{*}$ \\
\hline Hemoglobin $\left(\mathrm{g}^{-1}\right)$ & $120-160$ & $142(126-153)$ & $137(122-150.5)$ & $142.5(126-157)$ & 0.45 \\
\hline Hematocrit $(\%)$ & $35.0-51$ & $40.1(36.2-44.9)$ & $38.1(36.1-43.5)$ & $41(36.1-45.4)$ & 0.24 \\
\hline Basophil percentage (\%) & $0-1$ & $0.11(0-0.5)$ & $0.12(0-0.5)$ & $0.11(0-0.5)$ & 0.93 \\
\hline Basophil count $\left(\times 10^{9} \mathrm{l}^{-1}\right)$ & $0.12-08$ & $0.01(0-0.04)$ & $0.01(0-0.03)$ & $0.01(0-0.04)$ & 0.64 \\
\hline Eosinophil percentage (\%) & $1-5$ & $0.5(0-3.2)$ & $0.4(0-1.7)$ & $0.5(0-3.2)$ & 0.78 \\
\hline Eosinophil count $\left(\times 10^{9} \mathrm{l}^{-1}\right)$ & $0.05-0.3$ & $0.03(0-0.17)$ & $0.02(0-0.08)$ & $0.03(0-0.17)$ & 0.66 \\
\hline \multicolumn{6}{|l|}{ Blood biochemistry } \\
\hline Albumin $\left(\mathrm{g} \mathrm{l}^{-1}\right)$ & $40-55$ & $40.4(36.1-43.5)$ & $36.1(33.5-38.6)$ & $41.7(38.3-45.2)$ & $<0.001^{*}$ \\
\hline Total protein $\left(\mathrm{g} \mathrm{l}^{-1}\right)$ & $62-85$ & $68(64-72.6)$ & $67.8(63-73.7)$ & $68.3(64.2-72.6)$ & 0.86 \\
\hline Creatinine $\left(\mu \mathrm{mol} \mathrm{l} \mathrm{l}^{-1}\right)$ & $40-88$ & $62.7(52.3-80.2)$ & $80.2(63.6-86.4)$ & $61.2(46.7-77.1)$ & $0.007^{*}$ \\
\hline Creatine kinase ( $\mathrm{U} \mathrm{l}^{-1}$ ) & $25-190$ & $70.5(50.8-112.8)$ & $102(49-169.3)$ & $68(51.2-96.6)$ & 0.08 \\
\hline Creatine kinase-MB $\left(\mathrm{U} \mathrm{l}^{-1}\right)$ & $0-24$ & $15(12.4-20)$ & $15.5(13-23)$ & $15(11.9-19.3)$ & 0.45 \\
\hline Lactate dehydrogenase $\left(\mathrm{U} \mathrm{l}^{-1}\right)$ & $109-245$ & $238.5(192.1-316.3)$ & $316(266.5-412.2)$ & $225.1(184.8-289.8)$ & $<0.001^{*}$ \\
\hline Alanine aminotransferase $\left(\mathrm{U} \mathrm{l}^{-1}\right)$ & $8-45$ & $21(14-37)$ & $28.8(15.4-48.1)$ & $18.9(13.6-35.3)$ & 0.31 \\
\hline Aspartate aminotransferase ( $\left.\mathrm{U} \mathrm{l}^{-1}\right)$ & $14-38$ & $27(21.3-35)$ & $31.5(25.2-50.3)$ & $25.6(20.2-32.1)$ & $0.019^{*}$ \\
\hline Total bilirubin ( $\mathrm{mmol} \mathrm{l}^{-1}$ ) & $2-20.4$ & $12.3(8.1-20.3)$ & $15.9(10-22.2)$ & $12(7.2-19.9)$ & 0.31 \\
\hline Total bile acid $\left(\mu \mathrm{mol} \mathrm{l}^{-1}\right)$ & $0-10$ & $4.5(1.9-7.8)$ & $4.5(2.2-8.1)$ & $4.1(1.7-7.6)$ & 0.42 \\
\hline Total cholesterol ( $\left.\mathrm{mmol} \mathrm{l}^{-1}\right)$ & $0-5.2$ & $3.7(3.1-4.4)$ & $3.3(2.9-4)$ & $3.8(3.2-4.4)$ & 0.08 \\
\hline Urea $\left(\mathrm{mmol} \mathrm{l}^{-1}\right)$ & $2-8.3$ & $4(3.3-4.9)$ & $4.6(3.7-5.8)$ & $3.9(3.1-4.6)$ & 0.07 \\
\hline Uric acid, $\left(\mu \mathrm{mol} \mathrm{l}^{-1}\right)$ & $150-450$ & $249.4(177.2-33)$ & $208.2(155.3-284.5)$ & $254.8(186.2-332.9)$ & 0.09 \\
\hline Potassium, $\left(\mathrm{mmol} \mathrm{l}^{-1}\right)$ & $3.5-5.3$ & $3.8(3.5-4.1)$ & $3.6(3.4-4)$ & $3.9(3.6-4.2)$ & 0.09 \\
\hline Sodium $\left(\mathrm{mmol} \mathrm{l}^{-1}\right)$ & $137-147$ & $141.4(138.4-144.5)$ & $137.1(134.8-142.7)$ & $142(139.2-145)$ & $0.016^{*}$ \\
\hline Glucose $\left(\mathrm{mmol} \mathrm{l}^{-1}\right)$ & $3.9-6.1$ & $7.1(5.7-9.9)$ & $9.4(7.7-14.3)$ & $6.3(5.5-8.5)$ & $0.001^{*}$ \\
\hline Myoglobin $\left(\mu \mathrm{gl}^{-1}\right)$ & $0-90$ & $57.4(48.3-71.2)$ & $58.8(51.7-72.2)$ & $57.3(47.2-70.9)$ & 0.81 \\
\hline Alkaline phosphatase $\left(\mathrm{U} \mathrm{l}^{-1}\right)$ & $35-125$ & $49.4(37.7-76.1)$ & $86.3(56.4-172.1)$ & $43.2(35.1-61.3)$ & $<0.001^{*}$ \\
\hline$\beta 2$ microglobulin ( $\mathrm{mg} \mathrm{l}^{-1}$ ) & $1-3$ & $2.7(2.1-3.8)$ & $3.2(2.5-4.1)$ & $2.6(2-3.6)$ & 0.06 \\
\hline Procalcitonin ( $\left.\mathrm{ng} \mathrm{ml}^{-1}\right)$ & $0-0.05$ & $0.03(0-0.05)$ & $0.04(0.02-0.09)$ & $0.03(0-0.05)$ & $0.031^{*}$ \\
\hline Erythrocyte sedimentation rate $\left(\mathrm{mm} \mathrm{h}^{-1}\right)$ & $0-15$ & $42(18.5-80.5)$ & $73(22.6-93.7)$ & $39(16-56)$ & 0.12 \\
\hline \multicolumn{6}{|l|}{ Coagulation function } \\
\hline Prothrombin time (s) & $8-14$ & $11.1(10.4-12)$ & $11.3(10.5-12)$ & $11(10.3-12.1)$ & 0.67 \\
\hline Thrombin time $(\mathrm{s})$ & $14-21$ & $17.3(16.4-17.8)$ & $16.6(16.2-17.7)$ & $17.3(16.5-18)$ & 0.16 \\
\hline Activated partial thromboplastin time (s) & $20-40$ & $30.2(26.3-37)$ & $33.5(30.1-39.7)$ & $29(23.1-36.7)$ & $0.021^{*}$ \\
\hline D-dimer (mg l-1) & $0-0.55$ & $0.29(0.16-0.47)$ & $0.48(0.28-0.7)$ & $0.21(0.16-0.43)$ & $0.003^{*}$ \\
\hline
\end{tabular}

All of these data were collected on admission. Data were expressed as median (IQR), and Inequality hypothesis tests were done with Mann-Whitney U test. ${ }^{*} p<0.05$ was considered to be significant difference between groups. 
medRxiv preprint doi: https://doi.org/10.1101/2020.06.12.20129460; this version posted June 14, 2020. The copyright holder for this preprint (which was not certified by peer review) is the author/funder, who has granted medRxiv a license to display the preprint in perpetuity.

All rights reserved. No reuse allowed without permission.

Extend Data | Table 3. Anti-SARS-CoV-2 spike antibody responses in recovered COVID-19 patients

\begin{tabular}{|c|c|c|c|c|c|c|c|c|c|c|}
\hline \multirow{3}{*}{ Patient ID } & \multirow{2}{*}{\multicolumn{2}{|c|}{$\begin{array}{l}\text { Endpoint titer } \\
\text { SARS-CoV-2 }\end{array}$}} & \multirow{2}{*}{\multicolumn{2}{|c|}{$\begin{array}{c}\text { Avidity index (\%) } \\
\text { SARS-Cov-2 }\end{array}$}} & \multicolumn{3}{|c|}{ Cross-reaction } & \multirow{2}{*}{\multicolumn{3}{|c|}{ Neutralization $\left(\mathbf{I D}_{50}\right)$}} \\
\hline & & & & & \multirow{2}{*}{$\begin{array}{l}\text { SARS-CoV } \\
\text { S1 }\end{array}$} & \multicolumn{2}{|c|}{ MERS- CoV } & & & \\
\hline & S1 & S2 & S1 & S2 & & S1 & S2 & SARS-CoV-2 & SARS-CoV & MERS-CoV \\
\hline \multicolumn{11}{|c|}{ Severe $(n=17)$} \\
\hline PT1 & 14960 & 81920 & 44 & 48 & + & - & + & 735 & $<30$ & $<30$ \\
\hline PT2 & 40960 & 655360 & 28 & 80 & + & - & + & 728 & 253 & $<30$ \\
\hline PT3 & 40960 & 327680 & 22 & 46 & + & - & + & 2067 & $<30$ & 35 \\
\hline PT 4 & 40960 & 40960 & 54 & 63 & + & - & + & 1037 & 406 & $<30$ \\
\hline PT 5 & 40960 & 81920 & 59 & 63 & + & - & + & 686 & $<30$ & 68 \\
\hline PT6 & 81920 & 327680 & 57 & 67 & + & - & + & 3397 & 476 & $<30$ \\
\hline PT7 & 40960 & 327680 & 29 & 29 & + & - & + & 1750 & 73 & $<30$ \\
\hline PT8 & 81920 & 327680 & 57 & 60 & + & - & - & 1316 & 518 & $<30$ \\
\hline PT9 & 81920 & 655360 & 58 & 61 & + & - & - & 1625 & 98 & $<30$ \\
\hline PT10 & 81920 & 163840 & 41 & 72 & - & - & + & 1881 & 328 & $<30$ \\
\hline PT11 & 320 & 320 & NA & NA & - & - & - & $<30$ & $<30$ & $<30$ \\
\hline PT12 & 40960 & 327680 & 21 & 66 & - & - & + & 3457 & 513 & $<30$ \\
\hline PT13 & 81920 & 655360 & 26 & 60 & - & - & + & 1225 & 76 & 54 \\
\hline PT14 & 20480 & 327680 & 34 & 49 & - & - & + & 1898 & 30 & $<30$ \\
\hline PT15 & 20480 & 40960 & 55 & 49 & - & - & + & 403 & 426 & $<30$ \\
\hline PT16 & 40960 & 327680 & 30 & 29 & - & - & + & 495 & 249 & $<30$ \\
\hline PT17 & 81920 & 327680 & 37 & 64 & - & - & + & 1149 & 149 & 35 \\
\hline \multicolumn{11}{|c|}{ Non-severe $(n=50)$} \\
\hline PT18 & 20480 & 81920 & 37 & 70 & + & - & + & 218 & 409 & $<30$ \\
\hline PT19 & 81920 & 81920 & 47 & 66 & + & - & + & 631 & 209 & $<30$ \\
\hline PT20 & 40960 & 327680 & 44 & 77 & + & - & + & 859 & 160 & $<30$ \\
\hline PT21 & 81920 & 81920 & 47 & 62 & + & - & + & 722 & $<30$ & $<30$ \\
\hline PT22 & 81920 & 81920 & 52 & 58 & + & - & + & 585 & 423 & 53 \\
\hline PT23 & 81920 & 655360 & 40 & 41 & + & - & + & 1006 & 398 & $<30$ \\
\hline PT24 & 40960 & 40960 & 49 & 53 & + & - & + & 1673 & 133 & $<30$ \\
\hline PT25 & 40960 & 20480 & 27 & 39 & + & - & - & 558 & 191 & $<30$ \\
\hline PT26 & 81920 & 655360 & 37 & 49 & + & - & - & 3615 & 483 & $<30$ \\
\hline PT27 & 20480 & 81920 & 40 & 55 & + & - & + & 1168 & $<30$ & $<30$ \\
\hline PT28 & 20480 & 81920 & 45 & 41 & + & - & + & 1214 & $<30$ & $<30$ \\
\hline PT29 & 20480 & 655360 & 26 & 70 & + & - & + & 269 & $<30$ & 61 \\
\hline PT30 & 40960 & 163840 & 48 & 62 & + & - & + & 815 & $<30$ & 49 \\
\hline PT31 & 81920 & 327680 & 47 & 55 & + & - & + & 576 & 376 & $<30$ \\
\hline РT32 & 81920 & 327680 & 49 & 47 & + & - & + & 1395 & 141 & $<30$ \\
\hline PT33 & 40960 & 327680 & 23 & 55 & + & - & + & 956 & 159 & $<30$ \\
\hline PT34 & 40960 & 327680 & 15 & 58 & + & - & + & 2941 & 86 & $<30$ \\
\hline РT35 & 20480 & 40960 & 52 & 68 & - & - & + & 100 & 70 & $<30$ \\
\hline PT36 & 10240 & 81920 & 39 & 55 & - & - & - & 75 & 394 & $<30$ \\
\hline
\end{tabular}


medRxiv preprint doi: https://doi.org/10.1101/2020.06.12.20129460; this version posted June 14, 2020. The copyright holder for this preprint (which was not certified by peer review) is the author/funder, who has granted medRxiv a license to display the preprint in perpetuity. All rights reserved. No reuse allowed without permission.

\begin{tabular}{|c|c|c|c|c|c|c|c|c|c|c|}
\hline PT37 & 2560 & 81920 & 66 & 90 & - & - & + & 332 & 486 & $<30$ \\
\hline PT38 & 1280 & 5120 & 42 & 69 & - & - & - & $<30$ & $<30$ & $<30$ \\
\hline PT39 & 5120 & 655360 & 58 & 95 & - & - & + & 344 & 136 & $<30$ \\
\hline PT40 & 10240 & 20480 & 52 & 69 & - & - & + & 316 & 68 & $<30$ \\
\hline PT41 & 20480 & 20480 & 32 & 49 & - & - & - & 90 & 380 & $<30$ \\
\hline PT42 & 10240 & 81920 & 46 & 67 & - & - & + & 544 & $<30$ & $<30$ \\
\hline PT43 & 320 & 320 & NA & NA & - & - & - & 79 & $<30$ & $<30$ \\
\hline PT44 & 10240 & 40960 & 41 & 41 & - & - & + & 255 & 99 & 36 \\
\hline PT45 & 20480 & 81920 & 49 & 73 & - & - & + & 546 & 390 & $<30$ \\
\hline PT46 & 40960 & 81920 & 48 & 55 & - & - & + & 282 & 39 & $<30$ \\
\hline PT47 & 2560 & 81920 & 54 & 79 & - & - & + & 125 & 337 & $<30$ \\
\hline PT 48 & 320 & 320 & $\mathrm{NA}$ & NA & - & - & + & 42 & 309 & $<30$ \\
\hline PT49 & 20480 & 40960 & 34 & 57 & - & - & + & 215 & $<30$ & $<30$ \\
\hline PT50 & 40960 & 81920 & 23 & 52 & - & - & - & 1395 & 169 & $<30$ \\
\hline PT51 & 40960 & 327680 & 39 & 57 & - & - & + & 211 & 185 & $<30$ \\
\hline PT52 & 40960 & 81920 & 41 & 52 & - & - & + & 813 & $<30$ & 67 \\
\hline PT53 & 10240 & 81920 & 49 & 67 & - & - & - & 249 & 77 & $<30$ \\
\hline PT54 & 40960 & 81920 & 51 & 42 & - & - & - & 452 & $<30$ & $<30$ \\
\hline PT55 & 40960 & 163840 & 27 & 44 & - & - & + & 540 & 188 & $<30$ \\
\hline PT56 & 40960 & 327680 & 23 & 37 & - & - & + & 1433 & 420 & 272 \\
\hline PT57 & 2560 & 40960 & 49 & 51 & - & - & + & 395 & 248 & 34 \\
\hline PT58 & 5120 & 20480 & 56 & 61 & - & - & - & 113 & 440 & $<30$ \\
\hline PT59 & 10240 & 163840 & 56 & 53 & - & - & + & 1389 & 416 & $<30$ \\
\hline PT60 & 5120 & 5120 & 66 & 65 & - & - & - & 92 & $<30$ & $<30$ \\
\hline PT61 & 81920 & 81920 & 43 & 67 & - & - & - & 837 & 420 & $<30$ \\
\hline PT62 & 10240 & 81920 & 56 & 62 & - & - & + & 335 & 47 & $<30$ \\
\hline РT63 & 5120 & 81920 & 42 & 44 & - & - & + & 184 & 62 & $<30$ \\
\hline PT64 & 5120 & 40960 & 48 & 71 & - & - & - & 139 & 44 & $<30$ \\
\hline PT65 & 10240 & 81920 & 36 & 47 & - & - & + & 88 & 59 & $<30$ \\
\hline PT66 & 10240 & 81920 & 50 & 66 & - & - & - & 151 & 54 & $<30$ \\
\hline PT67 & 10240 & 40960 & 46 & 50 & - & - & - & 436 & 101 & 38 \\
\hline
\end{tabular}

Antibody binding titers to S1 and S2 of SARS-CoV-2 spike were performed by endpoint dilution assay and expressed as endpoint dilution. Cross-reactivity with SARS-CoV S1 and MERS-CoV S1 and S2 proteins were expressed positive (+) or negative (-). Neutralization (SARS-CoV-2) and cross-neutralization (SARS-CoV and MERS-CoV) were expressed as ID 50. $\mathrm{ID}_{50}>30$ was defined as positive according to the cutoff value of neutralization assay. 
medRxiv preprint doi: https://doi.org/10.1101/2020.06.12.20129460; this version posted June 14, 2020. The copyright holder for this preprint (which was not certified by peer review) is the author/funder, who has granted medRxiv a license to display the preprint in perpetuity.

All rights reserved. No reuse allowed without permission.

Extend Data | Table 4. SARS-CoV, MERS-CoV spike-specific antibody responses in healthy controls

Healthy control

SARS-CoV S1

MERS-CoV S1

MERS-CoV S2

\begin{tabular}{|c|c|c|c|}
\hline HC1 & - & - & - \\
\hline HC2 & - & - & - \\
\hline HC3 & - & - & - \\
\hline HC4 & - & - & - \\
\hline HC5 & - & - & - \\
\hline HC6 & - & + & - \\
\hline HC7 & - & - & - \\
\hline HC8 & - & - & - \\
\hline HC9 & - & - & - \\
\hline HC10 & - & - & - \\
\hline HC11 & - & - & - \\
\hline HC12 & - & - & - \\
\hline HC13 & - & - & - \\
\hline HC14 & - & - & - \\
\hline HC15 & - & - & - \\
\hline HC16 & - & - & - \\
\hline HC17 & - & - & - \\
\hline HC18 & - & - & - \\
\hline HC19 & - & - & - \\
\hline HC20 & - & - & - \\
\hline HC21 & - & - & - \\
\hline HC22 & - & - & - \\
\hline HC23 & - & - & - \\
\hline HC24 & - & - & - \\
\hline HC25 & - & - & - \\
\hline HC26 & - & - & - \\
\hline HC27 & - & - & - \\
\hline HC28 & - & - & - \\
\hline HC29 & - & - & - \\
\hline HC30 & - & - & - \\
\hline HC31 & - & - & - \\
\hline HC32 & - & - & - \\
\hline HC33 & - & - & - \\
\hline HC34 & - & - & - \\
\hline HC35 & - & - & - \\
\hline HC36 & - & - & - \\
\hline HC37 & - & - & - \\
\hline HC38 & - & - & - \\
\hline HC39 & - & - & - \\
\hline HC40 & - & - & - \\
\hline HC41 & - & - & - \\
\hline HC42 & - & - & - \\
\hline
\end{tabular}


medRxiv preprint doi: https://doi.org/10.1101/2020.06.12.20129460; this version posted June 14, 2020. The copyright holder for this preprint (which was not certified by peer review) is the author/funder, who has granted medRxiv a license to display the preprint in perpetuity. All rights reserved. No reuse allowed without permission.

\begin{tabular}{|c|c|c|c|}
\hline HC43 & - & - & - \\
\hline HC44 & - & - & + \\
\hline HC45 & - & - & - \\
\hline HC46 & - & - & - \\
\hline HC47 & - & - & - \\
\hline HC48 & - & - & - \\
\hline HC49 & - & - & - \\
\hline HC50 & - & - & - \\
\hline HC51 & - & - & - \\
\hline HC52 & - & - & - \\
\hline HC53 & - & + & - \\
\hline HC54 & - & - & - \\
\hline HC55 & - & + & - \\
\hline HC56 & - & + & - \\
\hline HC57 & - & - & - \\
\hline HC58 & - & - & - \\
\hline HC59 & - & - & - \\
\hline HC60 & - & - & - \\
\hline HC61 & - & - & - \\
\hline
\end{tabular}

Antibody responses with SARS-CoV S1 and MERS-CoV S1 and S2 proteins were expressed in healthy controls. Data presented as positive $(+)$ or negative $(-)$ 


\begin{tabular}{|c|c|c|c|c|c|c|c|c|c|c|c|c|c|}
\hline $\begin{array}{l}\text { Patient } \\
\text { ID }\end{array}$ & ANA titer & $\begin{array}{c}\text { Anti-ds-DNA } \\
\text { ( IU/ml ) }\end{array}$ & Nucleosomes & Histones & SmD1 & U1-SnRNP & $\begin{array}{l}\text { SS-A/Ro } \\
\text { (60 kDa) }\end{array}$ & $\begin{array}{l}\text { SS-A/Ro } \\
\text { (52 kDa) }\end{array}$ & SS-B/La & Scl-70 & CENP-B & jo-1 & $\begin{array}{r}\text { Anti-P0 } \\
(38 \text { kDa) }\end{array}$ \\
\hline PT1 & $1: 20$ & 28 & - & - & - & - & + & - & - & - & - & - & - \\
\hline PT2 & $<1: 20$ & 38 & - & - & + & - & - & - & - & - & - & - & - \\
\hline PT3 & $<1: 20$ & 27 & - & - & - & - & - & - & - & - & - & - & - \\
\hline PT 4 & $<1: 20$ & 103 & - & - & - & - & - & - & - & - & - & - & - \\
\hline PT5 & $<1: 20$ & 35 & - & - & - & - & - & - & + & - & - & - & - \\
\hline PT6 & $<1: 20$ & 64 & - & - & - & - & + & - & - & - & - & - & - \\
\hline PT7 & $<1: 20$ & 17 & - & - & - & - & - & - & - & - & - & - & - \\
\hline PT8 & $<1: 20$ & 54 & - & - & - & - & - & - & - & - & - & - & - \\
\hline PT9 & $<1: 20$ & 43 & - & - & - & - & - & - & - & - & - & - & - \\
\hline PT10 & $<1: 20$ & 24 & - & - & - & - & - & - & - & - & - & - & - \\
\hline PT11 & $<1: 20$ & 55 & - & - & - & - & - & - & - & - & - & - & - \\
\hline PT12 & $1: 20$ & 37 & - & - & - & - & - & - & - & - & - & - & - \\
\hline PT13 & $<1: 20$ & 88 & - & - & - & - & - & - & + & - & - & - & - \\
\hline PT14 & $<1: 20$ & 206 & - & - & - & - & - & - & - & - & - & - & - \\
\hline PT15 & $<1: 20$ & 31 & - & - & - & - & - & - & - & - & - & - & - \\
\hline PT16 & $<1: 20$ & 170 & - & - & - & - & - & - & - & - & - & - & - \\
\hline PT17 & $<1: 20$ & 23 & - & - & - & - & - & - & - & - & - & - & - \\
\hline PT18 & $<1: 20$ & 64 & - & - & - & - & - & - & + & - & - & - & - \\
\hline PT19 & $<1: 20$ & 35 & - & - & - & - & - & - & - & - & - & - & - \\
\hline PT20 & $<1: 20$ & 84 & - & - & - & - & - & - & - & - & - & - & - \\
\hline PT21 & $<1: 20$ & 50 & - & - & - & - & - & - & - & - & - & - & - \\
\hline PT22 & $<1: 20$ & 36 & - & - & - & - & - & - & - & - & - & - & - \\
\hline PT23 & $<1: 20$ & 46 & - & - & - & - & - & - & - & - & - & - & - \\
\hline PT24 & $<1: 20$ & 15 & - & - & - & - & - & - & - & - & - & - & - \\
\hline PT25 & $1: 40$ & 28 & - & - & - & - & - & - & - & - & - & - & - \\
\hline PT26 & $<1: 20$ & 40 & - & - & - & - & - & - & - & - & - & - & - \\
\hline PT27 & $<1: 20$ & 43 & - & - & - & - & - & - & - & + & - & - & - \\
\hline PT28 & $<1: 20$ & 33 & - & - & - & - & - & - & - & - & - & - & - \\
\hline PT29 & $<1: 20$ & 39 & - & - & - & . & - & - & - & - & - & - & - \\
\hline
\end{tabular}




\begin{tabular}{|c|c|c|c|c|c|c|c|c|c|c|c|c|c|}
\hline PT30 & $<1: 20$ & 44 & - & - & - & - & - & - & - & - & - & - & - \\
\hline PT31 & $1: 20$ & 63 & - & - & - & - & - & - & - & - & - & - & - \\
\hline PT32 & $<1: 20$ & 51 & - & - & - & - & - & - & - & - & - & - & - \\
\hline PT33 & $<1: 20$ & 30 & - & - & - & - & - & - & - & - & - & - & - \\
\hline PT34 & $1: 80$ & 51 & - & - & - & - & + & - & - & - & - & - & - \\
\hline PT35 & $<1: 20$ & 25 & - & - & - & - & - & - & - & - & - & - & - \\
\hline PT36 & $<1: 20$ & 52 & - & - & - & - & - & - & - & - & - & - & - \\
\hline PT37 & $<1: 20$ & 46 & - & - & - & - & - & - & - & - & - & - & - \\
\hline PT38 & $<1: 20$ & 19 & - & - & - & - & - & - & - & - & - & - & - \\
\hline PT39 & $<1: 20$ & 35 & - & - & + & - & - & - & - & - & - & - & - \\
\hline PT40 & $<1: 20$ & 30 & - & - & - & - & - & - & - & - & - & - & - \\
\hline PT41 & $<1: 20$ & 17 & - & - & - & - & - & - & - & - & - & - & - \\
\hline PT42 & $<1: 20$ & 98 & - & - & - & - & - & - & - & - & - & - & - \\
\hline PT43 & $<1: 20$ & 15 & - & - & - & - & + & - & + & - & - & - & - \\
\hline PT44 & $<1: 20$ & 152 & - & - & - & - & - & - & - & - & - & - & - \\
\hline PT45 & $<1: 20$ & 28 & - & - & - & - & - & - & - & - & - & - & - \\
\hline PT46 & $<1: 20$ & 22 & - & - & - & - & - & - & - & - & - & - & - \\
\hline PT47 & $<1: 20$ & 24 & - & - & - & - & - & - & - & - & - & - & - \\
\hline PT48 & $<1: 20$ & 58 & - & - & - & - & - & - & - & - & - & - & - \\
\hline PT49 & $<1: 20$ & 37 & - & - & - & - & - & - & - & - & - & - & - \\
\hline PT50 & $<1: 20$ & 43 & - & - & - & - & - & - & - & - & - & - & - \\
\hline PT51 & $1: 80$ & 50 & - & - & - & - & + & - & - & - & - & - & - \\
\hline PT52 & $1: 20$ & 15 & - & - & - & - & - & - & - & - & - & - & - \\
\hline PT53 & $<1: 20$ & 37 & - & - & - & - & - & - & - & - & - & - & - \\
\hline PT54 & $<1: 20$ & 81 & - & - & - & + & - & - & - & - & - & - & - \\
\hline PT55 & $<1: 20$ & 34 & - & - & - & - & - & - & - & - & - & - & - \\
\hline PT56 & $<1: 20$ & 24 & - & - & - & - & - & - & - & - & - & - & - \\
\hline PT57 & $<1: 20$ & 43 & - & - & - & - & - & - & - & - & - & - & - \\
\hline PT58 & $<1: 20$ & 28 & - & - & - & - & - & - & - & - & - & - & - \\
\hline PT59 & $<1: 20$ & 30 & - & - & - & - & - & - & - & - & - & - & - \\
\hline PT60 & $<1: 20$ & 32 & - & - & - & + & - & - & - & - & - & - & - \\
\hline
\end{tabular}

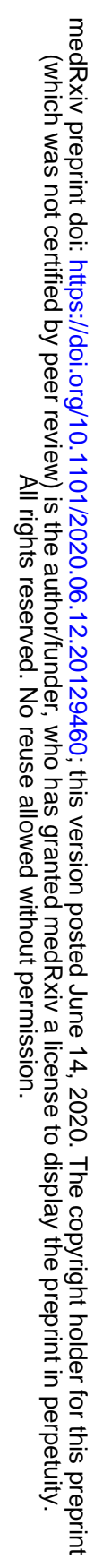




\begin{tabular}{|c|c|c|c|c|c|c|c|c|c|c|c|c|c|}
\hline PT61 & $<1: 20$ & 41 & - & - & - & - & - & - & - & - & - & - & - \\
\hline PT62 & $<1: 20$ & 41 & - & - & - & - & - & - & - & - & - & - & - \\
\hline PT63 & $<1: 20$ & 31 & - & - & - & - & - & - & - & - & - & - & - \\
\hline PT64 & $<1: 20$ & 201 & - & - & - & - & - & - & - & - & - & - & - \\
\hline PT65 & $<1: 20$ & 46 & - & - & - & - & - & - & - & - & - & - & - \\
\hline PT66 & $<1: 20$ & 54 & - & - & - & - & - & - & - & - & - & - & - \\
\hline PT67 & $<1: 20$ & 39 & - & - & - & - & - & - & - & - & - & - & - \\
\hline
\end{tabular}

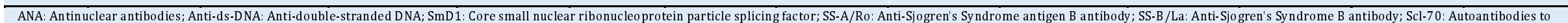

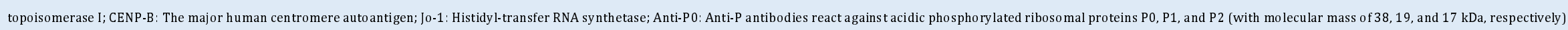

